DOMINIKA GRABIEC

INSTYTUT SZTUKI, POLSKA AKADEMIA NAUK

\title{
BIZANTYŃSKO-RUSKIE SCENY NAIGRAWANIA W KOLEGIACIE W WIŚLICY ORAZ W KAPLICY ŚWIĘTEJ TRÓJCY NA ZAMKU KRÓLEWSKIM W LUBLINIE W ŚWIETLE AKTUALNYCH BADAŃ I INTERPRETACJI
}

\begin{abstract}
\a temat bizantyńsko-ruskich malowideł ufundowanych przez Władysława Ja1 giełłę m.in. w kolegiacie wiślickiej oraz w kaplicy Świętej Trójcy na Zamku Królewskim w Lublinie wypowiedziało się już wielu badaczy historii malarstwa bizantyńsko-ruskiego na ziemiach polskich oraz konserwatorów ${ }^{\mathrm{I}}$. W ostatnich latach
\end{abstract}

I Zob. m.in.: Tadeusz M. Trajdos, „Treści ideowe wizerunków Jagiełły w kaplicy Św. Trójcy na zamku lubelskim”, Biuletyn Historii Sztuki 4I (I979) nr 3, s. 316-320; tegoż, „Treści ideowe i kręgi stylistyczne polichromii bizantyńskiej za panowania Władysława II Jagiełły”, Zeszyty Naukowe Wydziału Humanistycznego Uniwersytetu Gdańskiego. Slawistyka 3 (1982), s. I57-I70; Piotr Rudniewski, Mieczysław Samborski, „Problemy związane z pracami konserwatorskimi przy kaplicy Św. Trójcy na zamku w Lublinie”, Ochrona Zabytków 2I (1968) nr 3, s. I5-30; Piotr Grotowski, „Dwie nieznane sceny w prezbiterium kolegiaty wiślickiej”, w: Ars graeca. Ars latina. Studia dedykowane Profesor Annie Różyckiej-Bryzek, red. Wojciech Bałus, Waldemar Ceran i in., Kraków 200I, s. I45-I54, oraz liczne opracowania Anny Różyckiej-Bryzek: „Bizantyńsko-ruskie malowidła ścienne w kolegiacie wiślickiej”, Folia Historiae Artium 2 (1965), s. 47-82; „Zarys historyczny badań nad bizantyńsko-ruskimi malowidłami ściennymi w Polsce", Biuletyn Historii Sztuki 27 (1965), s. I75-293; „Byzantine Frescoes in Medieval Poland”, w: Actes du XXIIème Congrès International d'Histoire de l'art, Budapest, Septembre I969, Budapest I972, t. I, s. 225-23I; „Ikonografia malowideł ściennych w kaplicy Świętej Trójcy na zamku w Lublinie: wątek starotestamentowy i hagiograficzny”, Zeszyty Naukowe UJ. Prace z Historii Sztuki I2 (1976), s. 57-IIO; „Wyobrażenia aniołów w bizantyńsko-ruskich malowidłach kaplicy Świętej Trójcy w Lublinie I4I8”, Folia Historiae Artium I3 (1977), s. I9-52; „Uwagi o referacie T.M. Trajdosa pt. "Treści ideowe wizerunków Jagiełly w kaplicy Świętej Trójcy na zamku lubelskim»”, Biuletyn Historii Sztuki 43 (198I), s. 437-443; „Echa tradycji antycznych w bizantyńsko-ruskich malowidłach ściennych Sandomierza i Lublina”, w: Ars auro prior. Studia Joanni Biatostocki sexagenario dicata, red. Julian A. Chrościcki i in., Warszawa I98I, s. II5-I2O; „Realizacja bizantyńskiego programu ikonograficznego w polskich kościołach gotyckich na przykładzie malowideł kaplicy lubelskiej I4I8 r.”, w: Sztuka i ideologia XV wieku. Materiaty Sympozjum Komitetu Nauk o Sztuce PAN, red. Piotr Skubiszewski, Warszawa 1978, s. 403-425; Bizantyńsko-ruskie malowidta w kaplicy zamku lubelskiego, Warszawa I983; „Bizantyńsko-słowiańskie malowidła w gotyckich kościołach Polski pierwszych Jagiellonów”, w: Między Wschodem a Zachodem. Dzieje Lubelszczyzny, t. 6, cz. 2, Kultura artystyczna, red. Tadeusz Chrzanowski, Lublin 1992, s. 313-347; „Bizantyńsko-ruskie malowidła w Polsce wczesnojagiellońskiej: problem przystosowań na gruncie kultury łacińskiej”, w: Polska-Ukraina. Iooo lat sasiedztwa, t. 2, red. Stanisław Stępień, Przemyśl I994, s. 307-326; Wiślica: nowe badania i interpretacje, red. Andrzej Grzybkowski, Warszawa 
pojawiły się kolejne opracowania, które prezentują nowe ustalenia dotyczące kompozycji, programu ikonograficznego oraz treści poszczególnych malowideł², a także ich politycznej funkcji ${ }^{3}$, jak również przeprowadzonych prac konserwatorskich ${ }^{4}$. Nie wyczerpują one oczywiście wszystkich problemów i zagadnień, zwłaszcza że postęp badań nad sztuką bizantyńską różnych regionów świata w nowym świetle ukazuje także niektóre aspekty naszych rodzimych zabytków.

Z polecenia Władysława Jagiełły malowidłami bizantyńsko-ruskimi udekorowano nie tylko wiślicką kolegiatę i kaplicę zamkową w Lublinie, lecz także inne, ważne dla polskiego Kościoła świątynie, m.in. benedyktyński kościół Świętego Krzyża na Łyścu, katedrę gnieźnieńską, kolegiatę sandomierską (obecnie katedra), kaplicę mariacką i królewską komnatę sypialną na Wawelu oraz wiele kościołów na Litwie i Rusi, o których dziś już niewiele wiadomo5. Wśród zachowanych w całości lub fragmentarycznie zespołów malowideł jedynie w wiślickim i lubelskim można zobaczyć wkomponowane w cykl pasyjny sceny Naigrawania się z Chrystusa z motywem postaci grających na instrumentach muzycznych. Są one unikatowe nie tylko na terenie

1997; „O freskach lubelskich ponownie: uzupełnienia i dopowiedzenia”, w: Kaplica Trójcy Świętej na Zamku Lubelskim. Historia, teologia, sztuka, konserwacja. Materiaty sesji zorganizowanej w Muzeum Lubelskim 24-26 kwietnia I997, red. Barbara Paprocka, Jan A. Sil, Lublin I999, s. 9I-IO4; „Tematy maryjne w malowidłach kaplicy Trójcy Świętej zamku lubelskiego: ikonografia i znaczenie, miejsce w programie”, w: Ikona liturgiczna. Ewangelizacyjne przestanie ikonografii maryjnej, red. Kazimierz Pek, Warszawa I999, s. II5-I48; Freski bizantyńsko-ruskie fundacji Jagietty w kaplicy Zamku Lubelskiego, Lublin 200o; „Malowidła ścienne bizantyńsko-ruskie”, w: Malarstwo gotyckie w Polsce, t. I, red. Adam S. Labuda, Krystyna Secomska, Warszawa 2004, s. I55-184. Starsze badania omówione zostały przez Annę Różycką-Bryzek w pracach: „Bizantyńsko-ruskie malowidła ścienne”, s. 50 oraz Bizantyńsko-ruskie malowidta w kaplicy, s. I3-I4.

2 M.in.: Agnieszka Gronek, „O wątku ewangelicznym w bizantyńsko-ruskich malowidłach w wiślickiej kolegiacie", w: Doctus artifex. Studia ofiarowane profesorowi Jerzemu Gadomskiemu w siedemdziesiąta. rocznice urodzin, red. Wojciech Bałus, Wojciech Walanus, Marek Walczak, Kraków 2007, s. I79-I9I; Piotr Ł. Grotowski, „On the Margins of Meaning: Some Remarks on Gesture as Depicted in the Orthodox Frescoes of Roman Catholic Churches in Poland", Biuletyn Historii Sztuki 70 (2008) nr I, s. I63-176; Athanassios Semoglou, „Remarques sur certains archaismes iconographiques dans les peintures murales byzantinisantes de la Pologne au XV siècle”, Zograf 32 (2008), s. I5I-I62.

3 Grażyna Jurkowlaniec, „The Artistic Patronage of Ladislaus Jagiełło. Beyond the Opposition between Byzantium and the Renaissance”, w: Bizancjum a Renesansy. Dialog kultur, dziedzictwo antyku. Tradycja i wspótczesność, red. Michał Janocha i in., Warszawa 20I2, s. 27I-28I; Mirosław P. Kruk, „Malowidła Graeco opere fundacji Jagiellonów jako postulat unii państwowej i kościelnej oraz jedności Kościoła”, w: Między teologia a duszpasterstwem powszechnym na ziemiach Korony doby przedtrydenckiej. Dziedzictwo Średniowiecza i wyzwania XV-XVI wieku, red. Wacław Walecki, Warszawa 2017 (= Kultura Pierwszej Rzeczpospolitej w dialogu z Europą. Hermeneutyka wartości 5), s. I45-20I; Małgorzata Smorąg-Różycka, „Bizantyńskie freski w sandomierskiej katedrze: królewski dar na chwałę Bożą czy odblask idei Unii Horodelskiej?”, Zeszyty Naukowe Uniwersytetu Jagiellońskiego. Prace Historyczne I4I (20I4) nr 2, s. 235-255; Marcin Walkowiak, „Graeco Opere in Władysław Jagiełł’s Royal Power Theatre. Introduction to the Study", Res Historica 48 (2019), s. 77-IOI.

4 Jolanta Żuk-Orysiak, „Historia konserwacji malowideł bizantyńsko-ruskich z kaplicy Trójcy Świętej w Lublinie", Roczniki Humanistyczne 62 (2014) nr 7, s. 53-75.

5 A. Różycka-Bryzek, Bizantyńsko-ruskie malowidta w kaplicy, s. 9; Waldemar Deluga, „Byzantine Frescoes in Latin Churches of the Jagiellonian Age in Poland and Lithuania: History of the Discovery”, Arte Christiana Io6 (2008) nr 844, s. 24-34; Małgorzata Smorąg-Różycka, „Bizantyńskie freski w sandomierskiej katedrze”, s. 235-236; J. Żuk-Orysiak, „Historia konserwacji malowideł bizantyńsko-ruskich”, s. 54. 
Polski, ale całego regionu Europy Środkowo-Wschodniej i być może z tego powodu przez wiele lat nie podejmowano prób odczytania ich znaczenia, poprzestając na opisie ikonograficznym i wskazaniu ich bałkańskich paraleli ${ }^{6}$. Sceny takie są jednak powszechnie znane na obszarach objętych niegdyś kulturą bizantyńską, zwłaszcza na Bałkanach i w ostatnich latach budzą coraz większe zainteresowanie zarówno historyków sztuki, jak i muzykologów w wielu krajach. Należy mieć nadzieję, że konfrontacja polskich malowideł z dotychczasowymi ustaleniami badaczy oraz analiza porównawcza z większym, bo liczącym dziś już ponad siedemdziesiąt przykładów, korpusem ikonograficznym pomoże lepiej poznać i zrozumieć zamysł artystów, a być może wskaże też nowe kierunki dalszych poszukiwań. Sceny te są szczególnie interesujące przede wszystkim dla badaczy dawnego instrumentarium muzycznego z uwagi na bogaty materiał ikonograficzny, jakiego dostarczają, ale także dla muzykologów zajmujących się średniowieczną kulturą muzyczną, gdyż ukazują niecodzienny i zaskakujący kontekst muzykowania. Uważna analiza tych malowideł kwestionuje funkcjonującą dotychczas dosłowną i jednoznaczną interpretację postaci muzykantów jako szyderców, którzy kakofonicznym hałasem niepasujących do siebie instrumentów ośmieszają i ogłuszają Chrystusa, składając przewrotny hołd?.

\section{SCENA NAIGRAWANIA Z KOLEGIATY WIŚLICKIEJ}

Malowidła w Wiślicy są starsze od lubelskich. O tym, że powstały jeszcze pod koniec XIV w., dowiadujemy się jedynie pośrednio, z rachunków królewskich i kronik Jana Długosza ${ }^{8}$. Nie cieszyły one zbyt długo wiernych odwiedzających wiślicką kolegiatę, gdyż z powodu popękania ścian świątyni i złego stanu dekoracji, biskup Jan Zadzik polecił zamalować je już w I637 r., przez co z czasem o istniejącym niegdyś

6 Por.: A. Różycka-Bryzek, „Bizantyńsko-ruskie malowidła ścienne”, s. 64, 66; tejże, Bizantyńsko-ruskie malowidta w kaplicy, s. 77; tejże, „Realia muzyczne w bizantyńsko-ruskich malowidłach w Polsce czasów Jagiełły", w: Empiria w badaniach muzyki, red. Andrzej Rakowski, Warszawa 1986 (= Zeszyty Naukowe AMFC I4), s. I82-I85.

7 Por. m.in.: Dominika Grabiec, „Musical Motifs in Christ's Passion: The Mocking of Christ from the Holy Trinity Chapel at Lublin Castle and Miniatures from the Cracovian Dominican meditations (ca. I532)", w: The Musical Heritage of the Jagiellonian Era, red. Paweł Gancarczyk, Agnieszka Leszczyńska, Warszawa 20I2, s. 29-37; Agnieszka Gronek, Ikony Męki Pańskiej. O przemianach w malarstwie cerkiewnym ukraińsko-polskiego pogranicza, Kraków 2007, s. I05-I06; Łukasz Kozak, „Rota - ośla lira czy psalterium Dawida? Przykład ambiwalencji w średniowiecznej ikonografii muzycznej”, w: Sacrum - obraz i funkcja w spoteczeństwie średniowiecznym, red. Aneta Pieniądz-Skrzypczak, Jerzy Pysiak, Warszawa 2005, s. 405; Mirosław Perz, „The Sacred and the Profane in Polish Music Sources and Paintings of the Fifteenth Century", w: Ars musica - ars sacra, red. David Hiley, Wolfgang Horn, Tutzing 2007 (= Regensburger Studien zur Musikgeschichte 4), s. 4I-56; A. Różycka-Bryzek, Bizantyńsko-ruskie malowidta w kaplicy, s. 77; A. Różycka-Bryzek, „Realia muzyczne”, s. I82, I85.

8 Zob.: G. Jurkowlaniec, „The Artistic Patronage of Ladislaus Jagiełło”, s. 27I; A. Różycka-Bryzek, Bizantyńsko-ruskie malowidta w kaplicy, s. 9. 


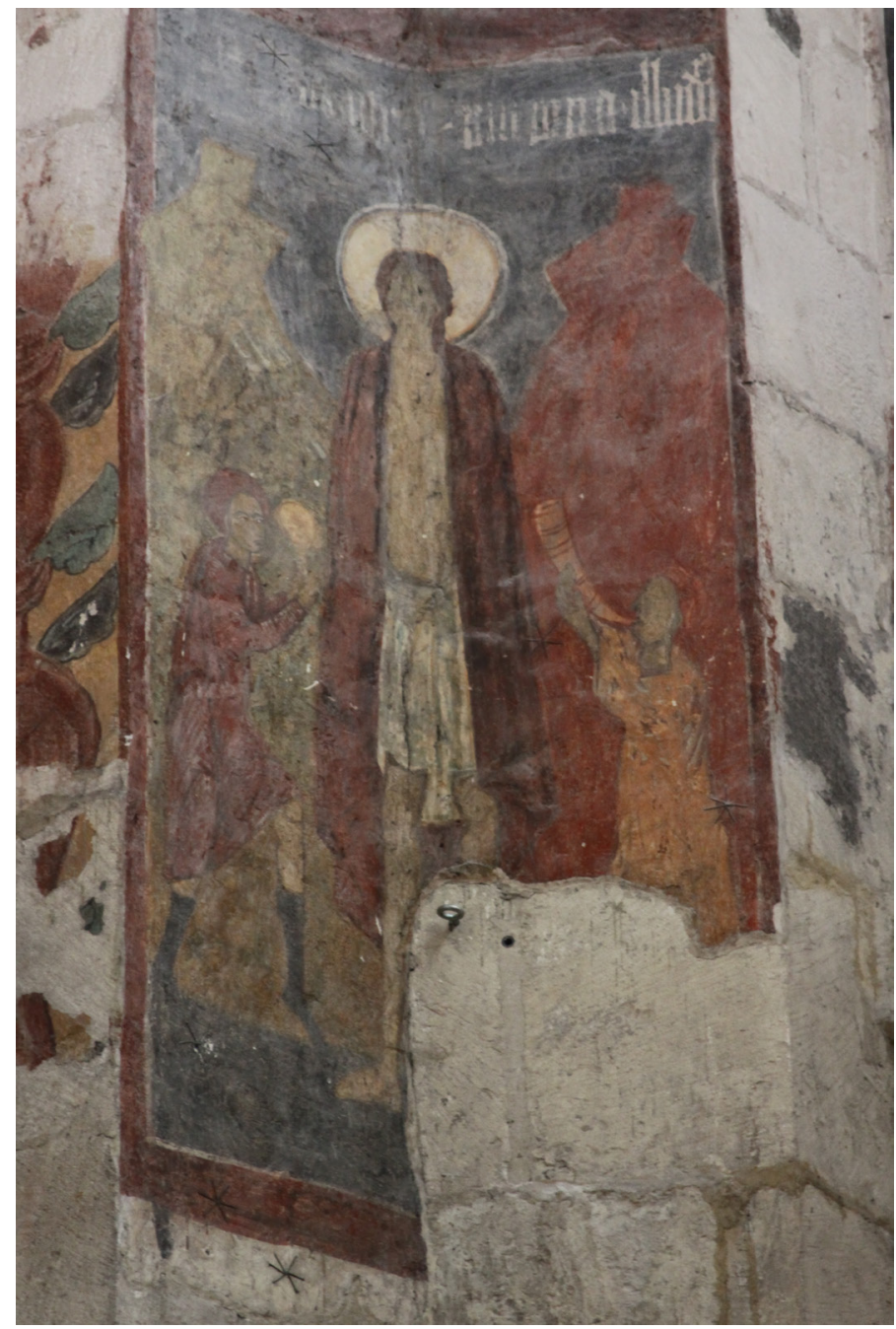

Il. I. Naigrawanie, malowidło ścienne, koniec XIV w., Bazylika kolegiacka Narodzenia Najświętszej Marii Panny w Wiślicy, fundacja króla Władysława Jagiełły, fot. prof. Grzegorz Kostecki ${ }^{9}$

średniowiecznym wystroju kościoła całkowicie zapomniano ${ }^{\mathrm{Io}}$. Malowidła zostały ponownie odkryte dopiero w I9I4 r. na skutek działań wojennych, które uszkodzity mury i odsłoniły fragmenty fresków zachowane pod warstwami pobiały. Już po wojnie, w l. 1919-22, zdjęto pokłady tynku i do 1930 r. przeprowadzono prace konserwatorskie pod kierunkiem Adolfa Szyszko-Bohusza. Kolejne prace prowadzone

9 Serdeczne podziękowania składam Księdzu Wiesławowi Stępniowi, Proboszczowi Bazyliki kolegiackiej w Wiślicy, za pomoc w uzyskaniu tej ilustracji oraz Profesorowi Grzegorzowi Kosteckiemu za wykonanie zdjęcia i zgodę na jego publikację

Io Zob.: P. Grotowski, „Dwie nieznane sceny”, s. I45. 
były w 1. 1959-66 oraz I994-99. W wyniku tych ostatnich odsłonięto kolejne dwie nieznane wcześniej sceny ukazujące Chrzest Chrystusa oraz Wskrzeszenie Łazarza ${ }^{\text {II }}$.

Scena Naigrawania namalowana została w wąskiej przestrzeni pomiędzy oknami, w dolnym pasie malowideł, w absydzie prezbiterium. Jej prawy, dolny fragment uległ zniszczeniu i jest nieczytelny. Z uwagi na niewielkie rozmiary powierzchni malowidła, ta rozbudowana zwykle w malarstwie bizantyńskim scena została tutaj zredukowana do trzech postaci: Chrystusa i dwóch muzykantów (zob. il. I). Jest to jedyny znany dziś tak skromny przykład bizantyńskiej redakcji Naigrawania z motywami muzycznymi. Niestety ani Naigrawaniu, ani pozostałym trzem scenom pasyjnym umieszczonym w absydzie nie towarzyszą w górnym pasie sceny ewangeliczne, które mogłyby podpowiedzieć ich teologiczne rozumienie, jak ma to miejsce w przypadku scen namalowanych na południowej i północnej ścianie kolegiaty ${ }^{\mathrm{I} 2}$.

W centrum kompozycji znajduje się stojący Chrystus, ukazany frontalnie. Jest przepasany białym perizonium nie sięgającym kolan, podobnie jak w scenie Biczowania namalowanej obok po lewej stronie, a na ramiona narzucony ma szkarłatny płaszcz zakrywający ręce, ale nie zasłaniający całego, obnażonego ciała, co jest nietypowe w bizantyńskich scenach Naigrawania. Na żadnym ze znanych malowideł nie występuje takie rozwiązanie. Zazwyczaj strojem Chrystusa była długa ciemna tunika, a płaszcz okrywał całe ciało. Wiślicka wersja jest bardziej zbliżona do gotyckich scen Koronowania Cierniami w malarstwie zachodnim ${ }^{\mathrm{I} 3}$. Z uwagi na stan zachowania malowidła trudno stwierdzić, czy Chrystus ma na nogach sandały, czy stopy są bose. Bizantyńscy malarze stosowali dowolnie oba rozwiązania, podobnie jak w przypadku korony cierniowej, która akurat na wiślickim malowidle nie jest widoczna.

Por:: A. Gronek, „O wątku ewangelicznym”, s. I79; P. Grotowski, „Dwie nieznane sceny”, s. I46-I47, I50; A. Różycka-Bryzek, „Bizantyńsko-ruskie malowidła ścienne”, s. 50; tejże, Bizantyńsko-ruskie malowidta w kaplicy, s. Io.

I2 Autorzy zwracali uwagę na nietypowy dla malarstwa bizantyńskiego układ i chronologię scen cyklu maryjnego i chrystologicznego w wiślickiej kolegiacie, por. m.in.: A. Różycka-Bryzek, „Bizantyńsko-ruskie malowidła ścienne”, s. 7I-73; A. Gronek, „O wątku ewangelicznym”. Należałoby natomiast zauważyć również, że treść i teologiczne znaczenie scen w górnym pasie dopełniają sceny w pasie dolnym, np. scenie Zwiastowania w górnym pasie towarzyszy Wjazd do Jerozolimy w dolnym. W pierwszym przypadku Anioł zwiastuje Maryi, że pocznie Syna Najwyższego, który obejmie tron praojca Dawida, w drugim przypadku Chrystus zostaje rozpoznany przez Żydów jako Mesjasz i witany jako król. Scena Bożego Narodzenia ukazująca Wcielenie Słowa Bożego, została zestawiona w dolnym pasie z Ostatnią Wieczerzą, podczas której Chrystus, ustanawiając Eucharystię, przemienia chleb w swoje Ciało i daje je jako pokarm. Scena Chrztu w Jordanie, ukazująca objawienie Syna Bożego który podejmuje misję zbawienia, zestawiona jest z Ukrzyżowaniem, czyli wypełnieniem tej misji poprzez złożenie dobrowolnej zbawczej ofiary za grzechy świata. Najwyraźniej zaburzenie chronologii w obu cyklach było celowym i przemyślanym zabiegiem służącym uwypukleniu najważniejszych treści teologicznych.

I3 Podobne przykłady w malarstwie wschodnim są znacznie późniejsze. M.in. jeden z nich, datowany na I593 r., przywołuje ks. bp Michał Janocha w swojej książce Ukraińskie i biatoruskie ikony świąteczne w dawnej Rzeczpospolitej. Problem kanonu (Warszawa 2002, zob. il. 16I). Jest to ikona Mistrza Przemienienia z Jabłonowa ze sceną Koronowania Cierniami i Naigrawania wzorowaną na malarstwie zachodnioeuropejskim. Chrystus ukazany jest tam właśnie w białej przepasce i płaszczu. Inny, jeszcze późniejszy przykład, to scena Naigrawania w serbskim monasterze w Bođani (Bodjani) datowana na 1737 r., zob.: Roksanda Pejović, Predstave muzickih instrumenata u srednjovekovnoj Srbiji, Beograd 1984, zob. il. 69. 
Po obu stronach Chrystusa ukazano dwie postaci znacznie mniejszych rozmiarów z instrumentami muzycznymi. Podobne pojawiają się na wielu bizantyńskich przedstawieniach Naigrawania w roli instrumentalistów bądź tancerzy i są przez niektórych autorów interpretowane jako postaci dziecięce ${ }^{\mathrm{I}}$. Chodzi tu jednak prawdopodobnie raczej o podkreślenie niższej hierarchii społecznej tych osób ${ }^{15}$. Postać po prawej stronie, skierowana ku Chrystusowi, ma na sobie szatę w kolorze żółtym i dmie w trzymany oburącz róg, unosząc go w górę. Instrument ma jasną barwę i widoczne zdobienia $\mathrm{w}$ postaci pierścieni, a jego forma przypomina powszechne w średniowieczu rogi zwierzęce znane m.in. z licznych przykładów ikonograficznych z terenu całej Europy. Z kolei postać po lewej ma na sobie czerwoną tunikę sięgającą do kolan, nakrycie głowy w tym samym kolorze i czarne buty. W uniesionych dłoniach trzyma instrument perkusyjny, prawdopodobnie mały bębenek obręczowy, w który uderza pałeczką. Na żadnej ze znanych bizantyńskich scen Naigrawania nie można odnaleźć dosłownego pierwowzoru tych konkretnych instrumentalistów. Wprawdzie wszystkie malowidła znacząco różnią się między sobą, zwłaszcza pod względem liczby muzykantów oraz rodzaju i form instrumentów, a wśród wszystkich znanych dziś przykładów nie ma dwóch identycznych scen, to jednak na wielu malowidłach, zwłaszcza z terenu Bałkanów, można zaobserwować pewne powtarzające się, niemal identyczne postaci i motywy, w tym też instrumenty, a nawet gesty i postawy muzyków i tancerzy. Tymczasem instrumentaliści ukazani na malowidle w Wiślicy nie mają bezpośrednich odpowiedników. Jedynie na dwóch przykładach mołdawskich z XVI w. (w kościele św. Krzyża w Pătrăuţi oraz w kościele św. Demetriusza w Suczawie, dziś w Rumunii) znalazły się bębenki obręczowe, ale znacznie większe niż wiślicki. Trzy z nich są uderzane dłonią, jeden długą, cienką pałeczką ${ }^{16}$. We wszystkich tych przypadkach chodzi prawdopodobnie o instrumenty charakterystyczne dla tamtego regionu ${ }^{17}$. Podobnie w przypad-

I4 Zob. m.in.: Svetozar Radojčić, „Ruganje Hristu na fresci u Starom Nagoričinu”, w: tegoż, Uzori i dela starih srpskih umetnika, Beograd 1975, s. I74-175; Kono Keiko, „Notes on the Dancers in the Mocking of Christ at Staro Nagoročino", Deltion of the Christian Archaeological Society 27 (2006), nr 4, s. I59-168, zob. zwł. s. I59, I62-I63; A. Gronek, Ikony Męki Pańskiej, s. I06. Anna Różycka-Bryzek określa te postaci jako „małych pachołków”, por.: A. Różycka-Bryzek, „Realia muzyczne w bizantyńsko-ruskich malowidłach”, s. I85. Również postaci tancerzy występujące w niektórych bałkańskich scenach Naigrawania są zazwyczaj ukazywane w mniejszych wymiarach niż Jezus, a tylko wyjątkowo w bułgarskim Iwanowie tancerz jest postacią wyższą niż pozostałe, zob.: Dora Panayotova, Bulgarian Mural Paintings of the I4th Century, Sofia 1966, s. 51.

I5 Por.: Elena Boeck, „Simulating the Hippodrome: The Performance of Power in Kiev’s St. Sophia”, The Art Bulletin 9I (2009) nr 3, s. 290.

I6 Zob.: Gabriela Ilnitchi Currie, „Catalogus. A Corpus of Pictorial Representations of Musical Instruments and Dances in the Church Frescoes of Present-day Romania, Wallachia and Moldavia, ca. I350 to ca. I750", Imago Musicae 23 (2006-IO) s. I4O-I4I, I44, il. 35 i 38 a.

I7 Oczywiście w przypadku analizy instrumentów muzycznych w źródłach ikonograficznych należy zawsze brać pod uwagę, że mogą to być kopie znacznie starszych obrazów, często też pochodzących z innych regionów. W przypadku scen Naigrawania, poza tymi oczywistymi uwarunkowaniami, można jednak zaobserwować znaczące różnice $\mathrm{w}$ doborze instrumentarium w zależności od regionu i czasu powstania malowideł. 
ku rogu na wielu malowidłach, zwłaszcza tych datowanych na wiek XIV, pojawiają się różne formy tego instrumentu, ale żadna z nich nie przypomina wiślickiej. Takie rogi występowały natomiast powszechnie, w różnych kontekstach, w średniowiecznym malarstwie zachodnim. Z kolei instrumenty perkusyjne występowały w różnorodnych formach w zależności od regionu, dlatego trudno stwierdzić, czy bębenek namalowany w Wiślicy został zapożyczony z jakiegoś wzornika ikonograficznego, czy może malarz ukazał instrument znany w tym czasie na ziemiach polskich. Wydaje się jednak, że w przypadku wiślickiej sceny mamy do czynienia z oryginalnymi rozwiązaniami, z inspiracją lokalnym instrumentarium, bądź z zapożyczeniami ze sztuki zachodniej.

Tło kompozycji stanowią dwa schematycznie ukazane skaliste pagórki, których barwy kontrastują z ubraniami muzykantów i ciemnogranatowym niebem. W bizantyńskich scenach Naigrawania skały to rozwiązanie stosowane bardzo rzadko, scenerię tworzą zwykle elementy architektoniczne. Znanych jest dziś zaledwie kilka przykładów z motywem krajobrazu. Najstarszy z nich, z ok. I205-I5 r., znajduje się w gruzińskim monasterze Maryi Dziewicy w Timotesubani ${ }^{18}$. Dwa kolejne to malowidła bułgarskie: w Crkvacie w Iwanowie (poł. XIV w.) ${ }^{19}$ oraz w Berendé (ok. I325-50 ${ }^{20}$. Jeszcze inny, to znacznie późniejsze malowidło Greka o imieniu Mina w monasterze św. Mikołaja w rumuńskim Căluiu (ok. I590) ${ }^{21}$. Ten ostatni przykład, w którym Chrystus ukazany jest na tle granatowego nieba pomiędzy dwoma skalistymi pagórkami, najbardziej przypomina rozwiązanie zastosowane w Wiślicy, choć oczywiście, z uwagi na dzielące oba malowidła odległość i czas, nie można dopatrywać się tutaj bezpośrednich oddziaływań.

Scena ta ma całkowicie odmienny charakter i klimat niż dworska kompozycja z lubelskiego zamku. Te znaczące różnice między malowidłami, które powstały w podobnym okresie z fundacji tego samego króla Władysława Jagiełły, dodatkowo potwierdzają, że oba zespoły malowideł wyszły spod ręki różnych artystów.

\section{SCENA NAIGRAWANIA Z KAPLICY ŚWIĘTEJ TRÓJCY NA ZAMKU KRÓLEWSKIM W LUBLINIE}

Lubelskie malowidło ukazujące scenę Naigrawania jest lepiej zachowane i znacznie bardziej rozbudowane niż wiślickie (il. 2). Zostało ukończone io VIII I4I8 r. przez malarza o imieniu Andrzej, o czym dowiadujemy się z napisu fundacyjnego umieszczonego na ścianie kaplicy. Był to jeden z trojga malarzy pracujących w Lu-

I8 Por.: Ekaterina Privalova, Rospis' Timotesubani: issledovanie po istorii gruzinskoj srednevekovoj monumental'noj zhivopisi, Tbilisi i980, pl. 90.

I) Zob.: Gabriela Ilnitchi Currie, „The Emergence of a Paradigm: Representations of Musical Instruments in the Palaiologian Depictions of the "Mocking of Christ»", Imago Musicae 23 (2006-IO), s. 64, il. I7.

20 Zob.: Elka Bakalova, Stenopisite na crkvata pri sielo Berendé, Sofia I976, s. 42.

2 I Zob.: G. Ilnitchi Currie, „Catalogus”, s. I04, I08, il. 5. 


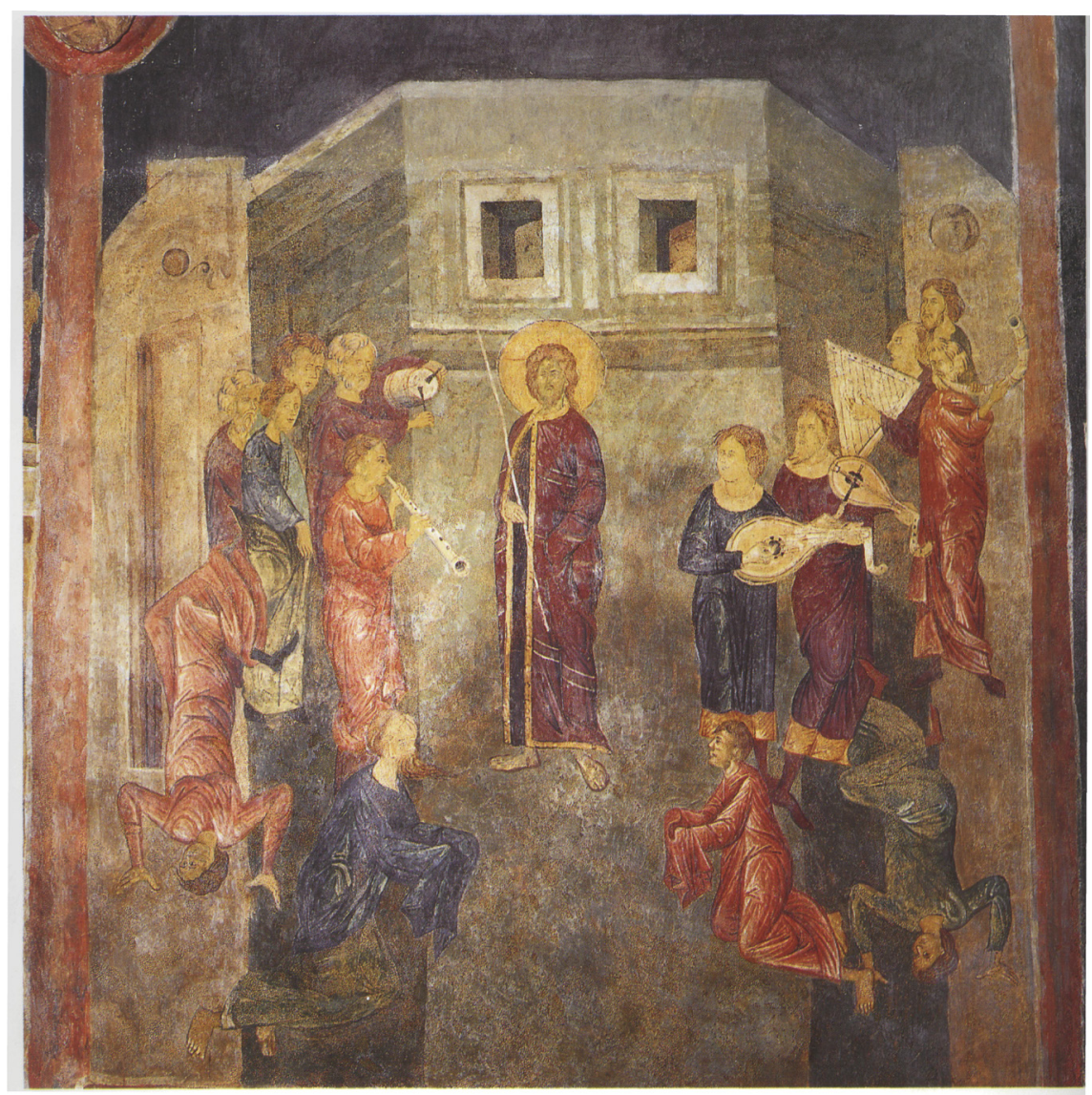

Il. 2. Naigrawanie z Chrystusa, malowidło ścienne, I4I8 r., Lublin, Zamek Królewski, Kaplica św. Trójcy, fundacja króla Władysława Jagiełły, fot. w: A. Różycka-Bryzek, Freski bizantyńsko-ruskie fundacji Jagietty, s. 156

blinie. To właśnie on namalował cykle narracyjne, w tym pasyjny, w którym odwołał się m.in. do wzorców serbskich i athoskich. Część malowideł wyszła spod ręki Cyryla (Kuryła), którego styl badacze określają jako pokrewny nowogrodzkiemu. Trzecim natomiast znanym z imienia malarzem był Juszko, pracujący w manierze archaicznej i pochodzący prawdopodobnie z regionu halicko-wołyńskiego lub kijowskiego. Wszyscy trzej mogli być prawosławnymi mnichami ${ }^{22}$.

Już na początku XIX w., zanim władze austriackie zamieniły zamek w więzienie, kaplica była w złym stanie. Zaborca nakazał zatynkować jej ściany, co przyczynito się do znacznego zniszczenia malowideł, ponadto pod koniec XIX w. dokonano

22 Por.: A. Różycka-Bryzek, Bizantyńsko-ruskie malowidta w kaplicy, s. 9; J. Żuk-Orysiak, „Historia konserwacji malowideł", s. 54-56. 
częściowej przebudowy. W 1. I897-99 odsłonięto pierwszy fragment malowideł, co wzbudziło ciekawość ówczesnych władz rosyjskich. W I903 r. Cesarska Komisja Archeologiczna z Petersburga odsłoniła prawie wszystkie malowidła, przy okazji część z nich bezpowrotnie uszkadzając. Prace konserwatorskie przeprowadzono dopiero w latach pięćdziesiątych i sześćdziesiątych XX w., następnie kontynuowano je w kolejnych dziesięcioleciach z przerwami, aż do początku XXI w. ${ }^{23}$.

Na lubelskim malowidle Chrystus ukazany został w długim purpurowym płaszczu przypominającym raczej cesarską chlamidę, niż okrycie rzymskiego żołnierza, na co wskazała Różycka-Bryzek ${ }^{24}$. Szata okrywa całą postać z wyjątkiem prawej dłoni trzymającej trzcinę i bosych stóp (ze względu na stan zachowania malowidła i jakość dostępnych fotografii trudno stwierdzić, podobnie jak w przypadku Wiślicy, czy są na nich sandały z cienkich rzemyków, czy stopy są całkowicie bose). Płaszcz okrywający w podobny sposób całą postać można zobaczyć jedynie na retabulum ołtarzowym w stylu bizantyńskim z końca XIII w., namalowanym dla konwentu św. Klary w Palma de Mallorca (dziś w Museu Diocesà w tym samym mieście) ${ }^{25}$, w scenie Naigrawania w kościele św. Krzyża w Agiasmati k. Platanistasa na Cyprze (I494) ${ }^{26}$ i w serbskim monasterze św. Jana Teologa w Poganowie (I499) ${ }^{27}$. Na większości pozostałych znanych przedstawień płaszcz jest bardziej rozchylony i często krótszy niż ciemnopurpurowa, cesarska tunika ozdobiona haftami, z reguły jednak zakrywa prawą rękę i odsłania jedynie lewą dłoń z trzciną. Takie rozwiązanie spotykane jest już od XI w., m.in. w Kapui, w Sant'Angelo in Formis (koniec XI w.) ${ }^{28}$, we wspomnianym już wyżej gruzińskim Timotesubani (początek XIII w.) oraz w kościele św. Mikołaja w Varoš, Prilep (I298 r.) ${ }^{29}$. Na drugim z wymienionych przykładów Chrystus ma na sobie białą, długą do ziemi tunikę z długimi rękawami, z szerokim ozdobnym haftem u dołu, natomiast na szkarłatnym płaszczu, na piersi znajduje się ozdobny złoty tablion noszony przez bizantyńskich cesarzy i dostojników. Motyw tablionu będzie się powtarzał w kolejnych stuleciach na wielu innych malowidłach bałkańskich, m.in. we wspomnianym Varoš, co prawdopodobnie oznacza, że odwoływano się do jakiegoś wspólnego, znanego wzorca ${ }^{30}$. Z kolei na innych malowidłach bałkańskich Chrystus ma na sobie jedynie długą, szkarłatną lub purpurową tunikę z krótkimi bądź długimi rękawami, m.in. w greckiej Tesalonice (dziś: Saloniki, I3IO-20), w Dečani

J. Żuk-Orysiak, „Historia konserwacji malowideł”, s. 57-6I, 66. Zob. też: A. Różycka-Bryzek, Bizantyńsko-ruskie malowidta $w$ kaplicy, s. I3.

24 A. Różycka-Bryzek, Bizantyńsko-ruskie malowidta w kaplicy, s. 77; tejże, „Realia muzyczne”, s. I82.

25 Por.: Column Hourihane, Pontius Pilate, Anti-semitism, and the Passion in Medieval Art, Pinceton 2009, s. 303 , il. I48.

26 Zob.: Karl Christian Felmy, Das Buch der Christus - Ikonen, Freiburg 2004, s. I09, il. 50.

27 Por.: R. Pejović, Predstave muzickih instrumenata, il. 34.

28 Zob.: G. Ilnitchi Currie, „The Emergence of a Paradigm”, s. 54, il. 5.

29 Zob.: Kosta Bałabanov, Macedonian Frescoes, Skopje i995, s. II2, fol. 60.

30 Zob.: G. Ilnitchi Currie, „The Emergence of Paradigm”, s. 66, il. 21 i 22; tejże, „Catalogus”, s. I35, il. 28, s. I36, il. 3I. 
(dziś w Kosowie, I340-50), Matejče (dziś w Kosowie, I356-60), oraz Iwanowie (Bułgaria, połowa XIV w.) ${ }^{31}$, skąd wniosek, że musiało istnieć przynajmniej kilka różnych wzorców stroju Chrystusa.

Głowę otacza złoty nimb krzyżowy. Korona cierniowa nie jest widoczna, co mogłoby wskazywać, że chodzi o pierwsze Naigrawanie, które miało miejsce po przesłuchaniu przez Wysoką Radę, choć trzcina trzymana w dłoni odwołuje do drugiego epizodu Naigrawania. Takie połączenie elementów dwóch opisów wyszydzenia jest często widoczne na bizantyńskich malowidłach. Scena rozgrywa się na dziedzińcu otoczonym murami. Jest to oryginalne i unikatowe rozwiązanie, ponieważ na większości malowideł Naigrawanie ma miejsce na tle murów miejskich, czy zabudowań, które nie stanowią zamkniętej przestrzeni.

Postaci wokół Chrystusa ukazane zostały w dwóch grupach rozmieszczonych symetrycznie po obu stronach. Jak podkreśliła Anna Różycka-Bryzek, wyjątkowy na tle innych bizantyńskich scen jest ich dystans i powściągliwość. Nie ma tu żołnierzy wtłaczających na głowę wieniec z cierni, nie ma pachołków uderzających Chrystusa trzciną po głowie, nikt nie szarpie i nie popycha, nie opluwa. Są tu jedynie instrumentaliści, wesołkowie stojący na głowie i osoby przyklękające z uniżeniem. Choć na wielu bizantyńskich malowidłach można również zaobserwować ten rodzaj czci i szacunku ze strony otoczenia, to jednak w przypadku lubelskiego malowidła jest on szczególnie widoczny ${ }^{32}$.

Wszystkie postaci ubrane są w długie szaty, nawet stojący na głowie akrobaci. Nie ma wśród nich ani jednego żołnierza, tak jak w Wiślicy, co należy do rzadszych wariantów. Podobne rozwiązanie zastosowano m.in. na wspominanych już malowidłach w Sant'Angelo in Formis (w scenie tej nie ma jeszcze motywu muzycznego), w Palma de Mallorca, w bułgarskim Iwanowie i w kościele Proroka Eliasza w Boboszewie (ok. I678) ${ }^{33}$, a także w kościele św. Jerzego w Staro Nagoričane (I3I7-I8) ${ }^{34}$, w rumuńskim monasterze św. Mikołaja w Probota (I532) 35 oraz na kilku innych średniowiecznych malowidłach serbskich.

$\mathrm{Na}$ pierwszym planie malarz umieścił symetrycznie, naprzeciwko siebie, dwóch klęczących mężczyzn z dłońmi zakrytymi długimi, szerokimi rękawami szat w kolorach granatowo-zielonym (postać po lewej stronie) i czerwonym (postać po prawej). Obaj mają bose stopy. Podobne postaci, ale w białych szatach, znalazły się na przywoływanym już malowidle z kościoła Krzyża Świętego w Agiasmati k. Platanistasa na Cyprze, ale sam motyw składania hołdu pojawił się znacznie wcześniej, bo widzimy go już pod koniec XI w. w Sant'Angelo in Formis, choć w tym przypadku poddani

3I Por.: G. Ilnitchi Currie, „The Emergence of Paradigm”, s. 6o, il. I3, s. 62, il. I4 i I6, s. 64, il. I7.

32 Por.: A. Różycka-Bryzek, „Realia muzyczne”, s. I85.

33 Zob.: Elena Floreva, The Church of the Prophet Eliah in Boboshevo, Sofia I978, s. 65, I49-150.

34 Ibid., s. 68, il. 23.

35 Zob.: G. Ilnitchi Currie, „Catalogus”, s. I40, I42, il. 36. 
nie mają osłoniętych rąk. Dłonie ukryte w rękawach widać natomiast m.in. na ukazującej Naigrawanie miniaturze z greckiego Ewangeliarza z ok. Iıoo r. (Paryż, BN, Ms. gr. 74, fol. 55I $)^{36}$, na malowidłach w kościele św. Andrzeja w Skopje (ok. I389) i w kościele św. Mikołaja w Curtea de Argeş w Rumunii (ok. I360) ${ }^{37}$ oraz w katolikonie św. Jerzego w rumuńskim monasterze w Voroneţ (ok. I490) ${ }^{38}$. Nie był to motyw powszechnie stosowany w scenach Naigrawania, ale z pewnością znany przynajmniej od końca XI w. w wielu regionach objętych wpływami kultury bizantyńskiej. Znacznie częściej ukazywano w tym miejscu przyklękających żołnierzy, zgodnie z relacją ewangeliczną. Przykładów takich jest więcej i pochodzą one z różnych okresów, np. malowidło w kościele Bogarodzicy Peribleptos w Ochrydzie w dzisiejszej Macedonii w I295 r. ${ }^{39}$, w kościele św. Mikołaja w Varoš, Prilep (również w Macedonii) z I298-9940, w kościele św. Mikołaja Orphanos w Tesalonice z I3IO-20 ${ }^{4 \mathrm{I}}$, w kościele Chrystusa Pantokratora w monasterze w Dečani z I340-50 ${ }^{42}$, we wspomnianym wyżej katolikonie św. Jerzego w monasterze w Voroneţ w Rumunii oraz na kilku szesnasto- i siedemnastowiecznych malowidłach z terenów dzisiejszej Rumunii i Mołdawii. Przyklękające postaci wykonują głęboki ukłon do ziemi praktykowany we wschodnim cesarstwie, tzw. proskynèse, oznaczający uniżenie poddanych przed wład$\mathrm{cą}^{43}$. Różycka-Bryzek odnotowuje, że motyw rąk zawiniętych w wydłużone rękawy charakteryzował tancerzy ${ }^{44}$. Choć takie postaci również pojawiają się na niektórych malowidłach ${ }^{45}$, to $\mathrm{w}$ tym przypadku nie mamy do czynienia z tańcem. Mężczyźni wyraźnie składają hołd, a zakrycie ich dłoni tkaniną jest, podobnie jak w innych scenach na bizantyńskich malowidłach, oznaką szacunku i czci ${ }^{46}$.

Tuż za klęczącymi malarz umieścił akrobatów stojących na głowie, po jednym z każdej strony. Mają na sobie długie suknie (które nie odsłaniają ciała pomimo wykonywanych akrobacji) w kolorach kontrastujących względem szat osób klęczących: wesołek po lewej ma szatę barwy czerwonawej i czarne buty, drugi natomiast zieloną i czerwone buty. Motyw akrobatów bardzo rzadko pojawiał się w scenach Naigrawania. Najstarszy znany przykład to przywoływane wyżej retabulum z Palma de Mal-

\footnotetext{
Zob.: G. Ilnitchi Currie, „The Emergence of a Paradigm”, s. 55, il. 7.

Ibid., s. 66, il. 21 i 22.

Zob.: G. Ilnitchi Currie, „Catalogus”, s. I47, il. $40 a$.

39 Zob.: G. Ilnitchi Currie, „The Emergence of a Paradigm”, s. 48, il. I.

40 Zob.: ibid., s. 6o, il. I2.

II Ibid., s. 6o, il. I3.

42 Ibid., s. 62, il. I4.

43 Zob.: André Grabar, L'empereur dans l'art byzantin, London I97I, s. 8I.

44 Zob.: A. Różycka-Bryzek, „Realia muzyczne”, s. I82.

$45 \mathrm{Na}$ niektórych malowidłach rękawy tancerzy są nienaturalnie wydłużone i wąskie, na innych z kolei szerokie i zwiewne, przypominają tradycyjne męskie i kobiece stroje ludowe niektórych regionów Gruzji. Na temat genezy i symboliki wydłużonych rękawów zob. np.: K. Keiko, Notes on the Dancers.

$46 \mathrm{~W}$ ten sam sposób mają też zakryte dłonie anioły kłaniające się przed Chrystusem na wiślickiej polichromii, zob.: P. Grotowski, „Dwie nieznane sceny”, s. I48.
} 
lorca (koniec XIII w.), na którym jedna z postaci na pierwszym planie ukazana jest w dynamicznym momencie wygięcia ciała ${ }^{47}$. Kolejny przykład, z połowy XIV w., to malowidło w bułgarskim Iwanowie, na którym stojący na rękach ma na sobie jedynie obcisły żółty strój ${ }^{48}$. Z kolei w scenie z Boboszewa (ok. I678) akrobata ma obcisłe żółte rajstopy, obcisłą białą bluzę i do złudzenia przypomina żonglerów na miniaturach w greckim kodeksie z XI w. (Wenecja, Biblioteca Marciana, Cod. gr. Z 549), na co zwróciła uwagę Gabriela Ilnitchi Currie ${ }^{49}$. Motyw akrobatów miał jednak nie średniowieczną, ale znacznie starszą, antyczną genezę, co odnotowali niektórzy badacze, m.in. Dora Panayotova ${ }^{50}, \mathrm{i}$, jak widać, był wykorzystywany jeszcze po wielu wiekach nawet w tak odległych regionach, jak Europa Środkowa.

$\mathrm{Na}$ drugim planie, po obu stronach Chrystusa, malarze umieścili dwie pięcioosobowe grupy instrumentalistów i śpiewaków. W grupie po lewej stronie jeden z mężczyzn gra na instrumencie dętym z wyraźnie zaznaczonymi otworami palcowymi, wąskim ustnikiem i rozszerzonym wylotem czary głosowej. Instrument, choć ukazany w uproszczeniu, różni autorzy odczytywali jako szałamajęer. Stojący za nim mężczyzna uderza dwoma krótkimi czarnymi pałeczkami w mały bębenek przytrzymywany lewym ramieniem. Trzej pozostali mężczyźni nie grają na instrumentach, ale mają otwarte usta, co sugeruje śpiew lub okrzyki. W grupie po prawej stronie mężczyzna stojący najbliżej Chrystusa gra na instrumencie strunowym szarpanym typu lutniowego. Do tej pory w publikacjach instrument utożsamiano z mandorą ${ }^{52}$, czyli popularnym w średniowieczu w Europie Zachodniej i Środkowej instrumentem lutniowym. Jednak mandora, podobnie jak lutnia, ma kształt bardziej podłużny, gruszkowaty, tymczasem korpus instrumentu na malowidle jest zaokraglony, a to wskazywałoby, że możemy mieć do czynienia raczej z kobzą, popularną na ziemiach polskich i w Europie Wschodniej ${ }^{53}$. Stojący obok muzyk gra na instrumencie strunowym smyczkowym interpretowanym dotychczas jako rebab (rebek) ${ }^{54}$, choć także w tym przypadku można wziąć pod uwagę jakiś instrument wschodnioeuropejski, np. popularne w Polsce gęśle, o których wyglądzie niewiele dziś wiemy, bądź bułgarską

47 Zob.: C. Hourihane, Pontius Pilate, s. 303, rys. 148.

48 Zob.: G. Ilnitchi Currie, „The Emergence of a Paradigm”, s. 64, il. I7. Przykład ten odnotowała już Anna Różycka-Bryzek w: Bizantyńsko-ruskie malowidta, s. 77.

49 Zob.: G. Ilnitchi Currie, „The Emergence of a Paradigm”, s. 64-65, il. 18-20.

50 D. Panayotova, Bulgarian Mural Paintings, s. 5I; Svetozar Radojčić, „Ruganje Hristu na fresci u Starom Nagoričinu”, Narodna Starina 35 (1939), s. I5-32.

5I Jerzy Banach, Tematy muzyczne w plastyce polskiej, Kraków I956, s. 9; A. Różycka-Bryzek, Bizantyńskoruskie malowidta w kaplicy, s. 77; M. Perz, The Sacred and the Profane, s. 42.

52 Ibid.

53 Taką sugestię wyraziła również Katarzyna Morawska, por.: tejże, Średniowiecze. Część 2: I320-I500, Warszawa 1998 (= Historia Muzyki Polskiej I), s. I69.

54 J. Banach, Tematy muzyczne, s. 9; A. Różycka-Bryzek, Bizantyńsko-ruskie malowidta w kaplicy, s. 77; K. Morawska, Sredniowiecze, s. I69; M. Perz, The Sacred and the Profane, s. 42. 
gadulkę, z uwagi na mniej wydłużony kształt pudła rezonansowego 55 . Byłoby to zresztą bardziej prawdopodobne także z uwagi na wschodnie pochodzenie malarzy. W głębi widzimy muzyka trzymającego trójkątne psalterium, czy może raczej harfę-psalterium ${ }^{56}$. Postać tuż obok niego dmie w duży, zakrzywiony róg, a w głębi widać twarz jeszcze jednego śpiewaka. Na żadnym ze znanych malowideł nie spotykamy takiego zestawienia instrumentów. Ten nietypowy dobór podkreśla lokalny, peryferyjny koloryt lubelskiego malowidła, nadaje mu dworski charakter, bez akcentów militarnych, tak częstych na bałkańskich malowidłach. Być może nieprzypadkowo ukazane tu instrumenty są zbliżone do tych, które spotykano na dworze Władysława Jagiełły. Rachunki królewskie z tego okresu wymieniają m.in. lutnistów, cytarzystów, harfistów, bandurzystów, fistulatorów, flecistów, trębaczy, bębnistów i oczywiście śpiewaków ${ }^{57}$. Na terenach Polski zachowało się niestety niewiele źródeł ikonograficznych z przykładami instrumentów muzycznych używanych w XIV i XV w., dlatego trudno dziś stwierdzić, podobnie jak w przypadku malowidła wiślickiego, czy malarz malował je według jakiegoś wzornika, czy z natury, ani czy odwzorowywał instrumenty, które widział w Polsce, czy te znane z rodzinnych stron. Pewne jest jedynie to, że dokonał unikatowego połączenia muzycznych motywów.

Wśród muzykantów są sami mężczyźni, co było regułą w scenach Naigrawania. Z kolei liczba wszystkich postaci grających, ewentualnie także tańczących oraz liczba i rodzaj instrumentów były w każdym przypadku zmienne. Te różnice pośrednio aczkolwiek wyraźnie wskazują, że nie liczba i rodzaj instrumentarium miały znaczenie dla odczytania treści, jaką niosły ze sobą muzyczne i taneczne motywy, ale sam fakt ich obecności. Często zresztą instrumenty ukazywane na przykładach pochodzących z różnych regionów miały cechy lokalnego instrumentarium i ewoluowały w kolejnych epokach wraz ze zmianami zachodzącymi w kulturze muzycznej, niosąc ze sobą być może także dodatkowe znaczenia ${ }^{58}$.

Malowidło lubelskie jest jednak wyjątkowe pod względem doboru instrumentów z uwagi na ich dużą różnorodność oraz przewagę instrumentów strunowych, które tylko sporadycznie pojawiały się w znanych scenach Naigrawania. Psalterium trapezowe ukazane zostało w cerkwi świętych Archaniołów Michała i Gabriela w Lesnowie k. Skopje (1349 r.) $)^{59}$, lira bizantyńska w monasterze w Dečani (ok. 1335-50) ${ }^{60}$, a lutnia, ze

W przypadku średniowiecznej ikonografii muzycznej należy zawsze uwzględnić schematyczność i umowność przedstawień, a także istnienie różnych form instrumentów, o których jeszcze zbyt mało wiemy.

56 Por.: Ł. Kozak, „Rota - ośla lira czy psalterium Dawida?”, s. 405.

57 K. Morawska, Średniowiecze, s. I43.

58 Zob.: R. Pejović, Predstave muzickih instrumenata. Gabriela Ilnitchi wspomina o pojawieniu się w pewnym momencie tureckich instrumentów wojskowych na malowidłach z terenów dzisiejszej Rumunii i Mołdawii, co mogło dodatkowo utożsamiać szyderców z tureckimi okupantami, zob.: G. Ilnitchi, „Ottoman Echoes, Byzantine Frescoes, and Musical Instruments in the Balkans”, w: Balkan Popular Culture and the Ottoman Ecumene: Music, Image, and Regional Political Discourse, red. Donna A. Buchanan, Lanham 2007 (= Europea: Ethnomusicologies and Modernities 6), s. 2IO; G. Ilnitchi Currie, „Catalogus”, op. cit.

59 Zob.: R. Pejović, Predstave muzickih instrumenata, il. I6.

6 Ibid., il. II. 
znacznie smuklejszą szyjką niż ta na lubelskim malowidle, w kościele św. Demetriusza w Banja Jošanica (Serbia) ${ }^{6}$. W scenach Naigrawania najczęściej malowano instrumenty perkusyjne i dęte. Często były to po prostu instrumenty wojskowe, wielkie bębny, kotty i talerze oraz długie trąby sygnałowe. Te ostatnie na wielu malowidłach tworzą jakby łuk nad głową Chrystusa. W przypadku Lublina mamy do czynienia wyłącznie z instrumentami używanymi w muzyce świeckiej. Ukazany tutaj mały bębenek, trzymany pod ramieniem, nie ma odpowiednika na żadnym ze znanych przedstawień. $\mathrm{Na}$ wielu z nich pojawiają się nieduże osznurowane bębenki dwumembranowe, podobne, ale większe i zwykle zawieszone na szyi, bądź na ramieniu. Jedynie na malowidle w Andreasz (Serbia) z 1389 r. mężczyzna przytrzymuje bębenek ramieniem, podobnie jak na przykładzie lubelskim ${ }^{62}$. Róg zwierzęcy również nie ma dosłownego odpowiednika na żadnym z pozostałych malowideł, bo przeważają na nich duże drewniane rogi, lekko tylko zakrzywione, rzadziej krótsze rogi zwierzęce (np. w kościele w Chilandarze (Grecja, ok. 1313), w Jašunie k. Leskovac (Serbia, I524) i w Velikej Hočy (Serbia, ok. 1580) ${ }^{63}$ ). $\mathrm{Na}$ żadnym przykładzie nie ma również instrumentu zbliżonego do lubelskiej szałamai. W Rumunii i Bułgarii pojawiają się znacznie krótsze zurny, we wspomnianym wyżej Chilandarze obok rogów namalowano krótką, lekko wygiętą szałamaję, również przypominającą róg. Wszystko to wskazuje wyraźnie na dużą niezależność i swobodę artystów tworzących lubelskie malowidło. $Z$ pewnością, podobnie jak malarze pracujący w Wiślicy, inspirowali się znanymi wzorcami, ale nie wahali się sięgać po własne motywy, odległe od powszechnie stosowanych w tym okresie na Bałkanach.

BIZANTYŃSKIE SCENY NAIGRAWANIA W ŚWIETLE NAJNOWSZYCH BADAŃ GENEZA MOTYWU I KONTEKST HISTORYCZNY

Wiślickie i lubelskie malowidła to odległe i stosunkowo późne przykłady bizantyńskiego modelu ikonograficznego Naigrawania z instrumentami muzycznymi i tancerzami ${ }^{64}$. Aktualny stan badań pozwala dziś na zarysowanie z większą precyzją, niż było to do niedawna możliwe, genezy motywów muzycznych w tych scenach. Pojawiły się one znacznie wcześniej, niż sądzono, długo przed ich rozkwitem na Bałkanach w ostatnich dziesięcioleciach XIII i w XIV wieku.

6I Ibid., il. 59 .

62 Ibid., il. 27.

63 Ibid., il. 3, 35, 47.

64 Obok niego istniał już w XIII w. odmienny, zachodni model, ukazujący Chrystusa siedzącego na tronie w otoczeniu szyderców, z których jeden lub dwaj dmą w róg. Temat zachodnich scen Naigrawania z motywem rogu zostanie szerzej omówiony w monografii autorki niniejszego artykułu, przygotowywanej na podstawie pracy doktorskiej pt. Przedstawienia Pasji w malarstwie wtoskim od XIII do XV w. Próba interpretacji symboliki trąb i rogów (Warszawa 20I7). Zostanie w niej również szerzej przedstawiona geneza scen Naigrawania z motywami muzycznymi oraz analiza poszczególnych źródeł. 
Scena Naigrawania zaczerpnięta została do malarstwa bezpośrednio z Ewangelii. Artyści często łączyli w niej elementy dwóch epizodów Naigrawania: pierwszego, po nocnym przesłuchaniu przed Wysoką Radą (Mt 26, 67-68; Mk I4, 53-65), czy jeszcze przed przesłuchaniem ( $€$ k 22, 63-65), i drugiego, po sądzie Piłata, ubiczowaniu i ukoronowaniu cierniami (Mt 27, 27-30; Mk I5, I6-19; J I9, 2-3). W sztuce scena ta pojawiła się stosunkowo późno, bo dopiero w IV w. i należała do rzadkich. Zachowały się tylko pojedyncze przykłady sprzed X wieku. Wzrost jej popularności w malarstwie bizantyńskim można zaobserwować od wieku XI, kiedy Naigrawanie zaczęto włączać do cykli pasyjnych na ikonach, miniaturach i malowidłach ściennych, co mogło być związane z wprowadzeniem nowych oficjów Wielkiego Tygodnia w klasztorach Konstantynopola ${ }^{65}$. W sztuce bizantyńskiej Naigrawanie ukazywano właściwie wyłącznie w ramach cykli pasyjnych, a nie samodzielnie, jak to miało miejsce na Zachodzie już w późnym średniowieczu ${ }^{66}$. Zachowane wczesne przykłady w malarstwie bizantyńskim i zachodnim w dużym stopniu różnią się od siebie, co sugeruje, że nie istniał jeszcze ściśle skodyfikowany model ikonograficzny. Na żadnym z najwcześniejszych przykładów nie pojawia się też pozaewangeliczny motyw instrumentalistów czy tancerzy.

Pierwsze znane dziś sceny z motywami tanecznymi datowane są na przełom XI i XII wieku. Są to miniatury w bizantyńskich Ewangeliarzach (Paryż, BN, Ms. gr. 74, fol. 55r; Florencja, Biblioteca Medicea Laurenziana, Ms. VI.23, fol. 58r i I6or), na których pojawia się postać mężczyzny wykonującego podskoki (w pierwszym przypadku), czy taneczne ruchy (na miniaturach z drugiego kodeksu), wydające się być szyderstwem z Chrystusa ${ }^{67}$ (zob. il. 3 i 4). Ponieważ nie znamy innych podobnych przykładów takich miniatur, trudno stwierdzić, czy były to unikatowe dekoracje tych konkretnych Ewangeliarzy, czy podobnych scen w malarstwie książkowym było więcej. Nie wiemy też, czy bezpośrednio poprzedzały one wyłonienie się popularnego później modelu, czy powstał on niezależnie od nich, jako jeden z wariantów scen Naigrawania.

Prawdopodobnie znacznie bliższa późniejszym wzorcom jest scena umieszczona na przenośnej ikonie kalendarzowej z klasztoru św. Katarzyny na Synaju, namalowanej przez gruzińskiego mnicha Ioannesa Tohabi. Ikona ukazuje pięć wizerunków Matki Bożej, historie cudów oraz cykl pasyjny. Choć fragment, na którym namalowana została scena Naigrawania, uległ znacznym uszkodzeniom, wciąż można zauważyć na

65 Zob.: A. Gronek, Ikony Męki Pańskiej, s. 32.

66 Louis Réau, Iconographie de l'Art Chrétien, t. 2, Iconographie de la Bible. Nouveau Testament, Paris 1957, s. 447-448; Gertrud Schiller, Ikonographie der christlichen Kunst, t. 2, Die Passion Jesu Christi, Gütersloh I968, s. 68, 79-83; G. Ilnitchi Currie, „The Emergence of a Paradigm”, s. 5I-55.

67 Por.: G. Ilnitchi Currie, „The Emergence of a Paradigm”, s. 55-57, il. 7-9; K. Keiko, „Notes on the Dancers”, s. I6o; Henry Maguire, „Parodies of Imperial Ceremonial and their Reflections in Byzantine Art”, w: Court Ceremonies and Rituals of Power in Byzantin and the Medieval Mediterranean. Comparative Perspectives, red. Alexander Beihammer, Stavroula Constantinou, Maria Parani, Leiden-Boston 2013, s. 423. 


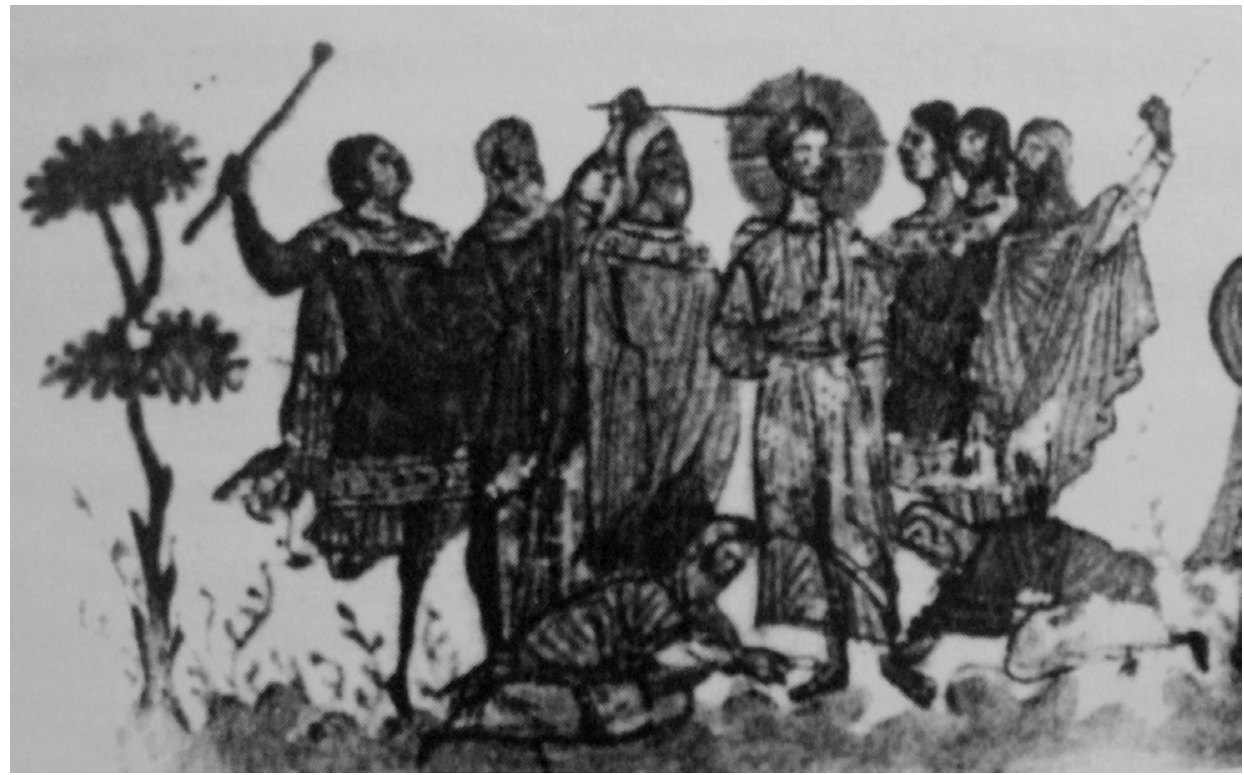

Il. 3. Naigrawanie z Chrystusa, miniatura, ok. IIoo r., ewangeliarz grecki, Bibliothèque Nationale w Paryżu, Ms. gr. 74, fol. 55r, fot. w: G. Ilnitchi-Currie, „The Emergence of a Paradigm”, s. 55, il. 7

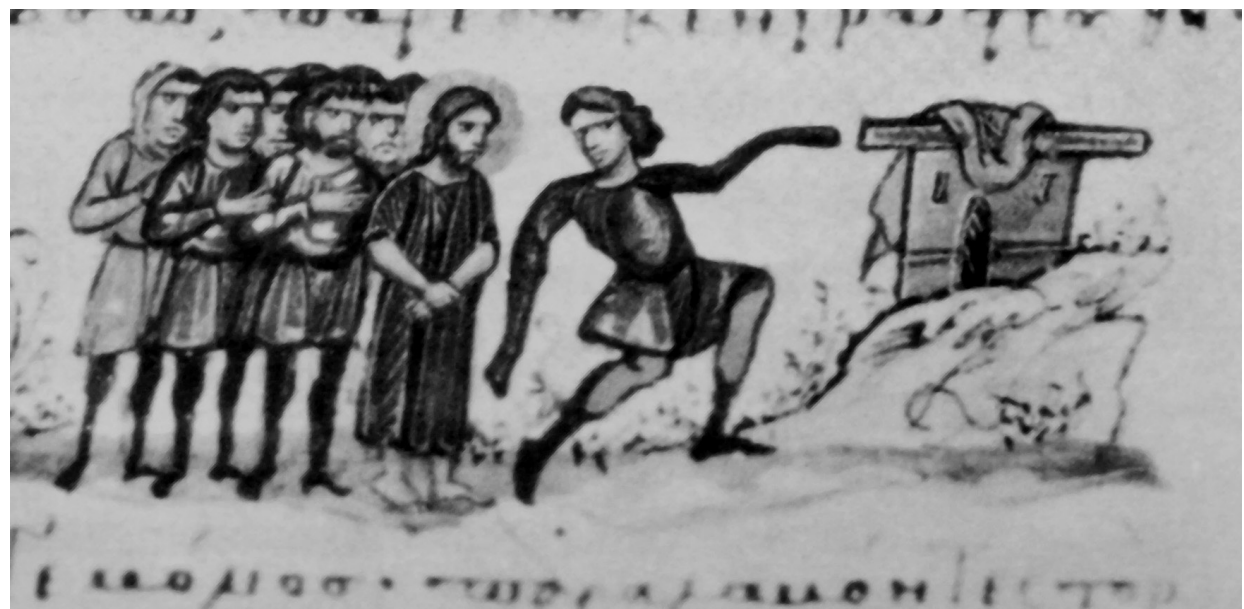

Il. 4. Naigrawanie z Chrystusa, miniatura, ok. IIoo r., ewangeliarz grecki, Florencja, Biblioteca Medicea Laurenziana, sygn. Ms. VI.23, fol. 58r, fot. w: G. Ilnitchi-Currie, „The Emergence of a Paradigm", s. 56-57, il. 8 
niej tańczącą postać oraz bębenek i róg ${ }^{68}$. Ikony Ioannesa, podobnie jak wspomniane miniatury, datowane są na przełom XI i XII w. ${ }^{69}$. Już w tym okresie musiała więc istnieć koncepcja włączenia do sceny Naigrawania motywów tańca i gry na instrumentach.

Proweniencja wspomnianych miniatur ${ }^{70}$ oraz synajskiej ikony wskazują, że ta zaskakująca idea pojawiła się prawdopodobnie w kręgach malarzy konstantynopolitańskich. Wiadomo, że gruziński mnich Ioannes przed udaniem się na Synaj spędził jakiś czas w Konstantynopolu, gdzie mógł zapoznać się z warsztatami tamtejszych artystów i nowymi wzorami ikonograficznymi ${ }^{71}$. Z uwagi na niewielką liczbę zachowanych źródeł z tego wczesnego okresu dokładniejsze ustalenie genezy scen Naigrawania z motywami muzycznymi nie jest w tym momencie możliwe. Pewne jest tylko to, że pojawiły się one najpóźniej na przełomie XI i XII w. w Bizancjum, prawdopodobnie w jednym z ośrodków malarskich Konstantynopola.

Kolejne zachowane przykłady, o sto lat późniejsze, to malowidła gruzińskie w przywoływanym już kilkakrotnie monasterze Maryi Dziewicy w Timotesubani (datowane na okres ok. I205-I5, zob. il. 5) ${ }^{72}$ oraz w monasterze Wniebowstąpienia w Ozaani (nieco wcześniejsze i niemal całkowicie już dziś zniszczone, ale pozostałe fragmenty wskazują na duże podobieństwo do sceny z Timotesubani) ${ }^{73}$. Ukazane tu postaci muzykantów, tancerzy i gladiatorów zwracają uwagę dużym podobieństwem do postaci skomorochów z wieży książęcej w kijowskim Soborze św. Zofii, namalowanych ok. I037 r. prawdopodobnie przez malarzy sprowadzonych z Konstantynopola. Kijowskie freski wzorowane były na ikonografii imperialnej, związanej z igrzyskami i wyścigami konnymi organizowanymi na konstantynopolitańskim Hipodromie ${ }^{74}$. Choć na temat gruzińskich malowideł nie ma zbyt wielu informacji, to prawdopodobne jest, że i one wzorowane były na podobnej ikonografii bizantyńskiej, być może nawet odwoływały się do tych samych motywów co starsze, kijowskie malowidła. Odmienny był jednak kontekst, w jaki motywy te zostały wplecione. Już od XI w.

68 Annemarie Weyl Carr, „Icons and the Object of Pilgrimage in Middle Byzantine Constantinople”, Dumbarton Oaks Papers 56 (2002), il. I. Kono Keiko wspomina o drugiej ikonie, na której odwrocie znajdują się sceny pasyjne, w tym scena Naigrawania z postacią tańczącą przed Chrystusem. Nie wspomina jednak, czy ikona ta należy również do zbioru Ioannesa, por.: K. Keiko, „Notes on the Dancers”, s. I6o.

69 Zob.: Maria Lidova, "The Artist's Signature in Byzantium. Six Icons by Ioannes Tohabi in Sinai Monastery (IIth-I2th Century)", Opera - Nomina-Historiae. Giornale di Cultura Artistica I (2009), s. 94, online http://onh.giornale.sns.it, dostęp 30 IV 2020; zob. też: G. Ilnitchi Currie, „The Emergence of a Paradigm”, s. 56, przyp. II, oraz K. Keiko, „Notes on the Dancers”, s. 159-I60.

70 Por.: Tania Velmans, La Tétraévangile de la Laurentienne, Florence, Laur.VI23, Paris I97I, s. I3.

7I M. Lidova, „The Artist's Signature in Byzantium”, s. 80, 85; tejże, „Creating a Liturgical Space: The Sinai Complex of Icons by Ioannes Tohabi”, w: Vakhtang Beridze Ist International Symposium of Georgian Culture: Georgian Art in the Context of European and Asian Cultures. Proceedings, June 2I-29, 2008 Georgia, red. Peter Skinner, Dimiti Tumanishvili, Anna Shanshiashvili, Tbilisi 2009, s. 226-23I, http://www. symposiumgeorgia.org/2008/Proceedings2008.pdf, dostęp 20 VII 2016.

72 G. Ilnitchi Currie, „The Emergence of a Paradigm”, s. 58-59; E. Privalova, Rospis' Timotesubani.

73 E. Privalova, Rospis' Timotesubani, s. 72, 215.

74 E. Boeck, „Simulating the Hippodrome”, s. 283, 287, 292; A. Grabar, L'empereur dans l'art byzantin, s. 64, 7I-72. 


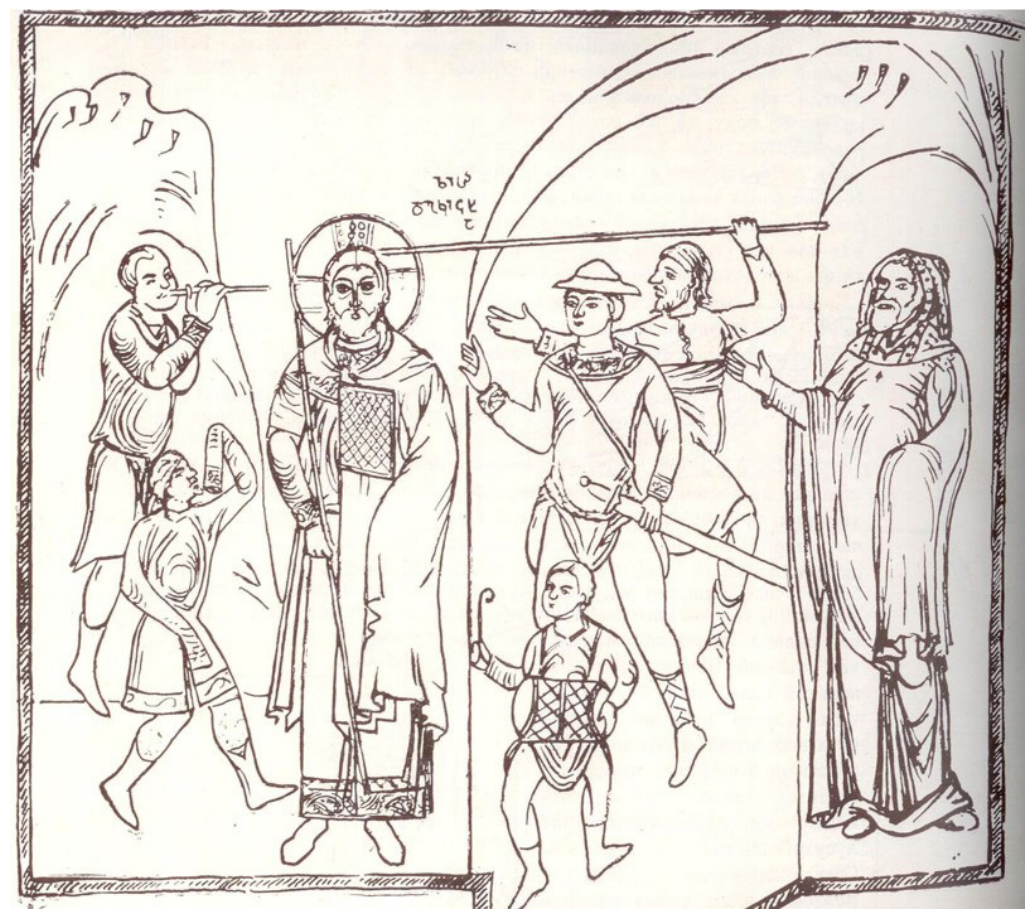

Il. 5. Naigrawanie z Chrystusa, malowidło ścienne (szkic), anonim, ok. I205-I215 r., klasztor Maryi Dziewicy w Timotesubani (Gruzja), fot. w: E. Privalova, Rospis' Timotesubani, s. 72, il. 27

wpływ sztuki bizantyńskiej był widoczny w gruzińskim malarstwie miniaturowym ${ }^{75}$, prawdopodobne jest więc, że i w przypadku malowideł ściennych wzorowano się na bizantyńskich wzorach.

Nie są dziś znane inne wczesne malowidła, choć musiało być ich znacznie więcej, gdyż te, które zostały namalowane pod koniec XIII w. na Bałkanach, były dużo bardziej rozbudowane i dojrzalsze pod względem artystycznym oraz formalnym w stosunku do wspomnianych wcześniej przykładów. Bałkańskie sceny stanowiły najpełniejszą formę modelu bizantyńskiego Naigrawania (zob. il. 6). Kopiowano je potem w różnych wariantach jeszcze nawet w XIX wieku. Pośrednim dowodem na liczniejszą obecność scen Naigrawania z motywami muzycznymi w XIII w. w różnych regionach świata objętego wpływami kultury bizantyńskiej jest wspominane już franciszkańskie retabulum Męki Pańskiej w stylu bizantyńskim Mistrza Pasji z Majorki (działał ok. I290-I305), datowane na koniec XIII w. ${ }^{76}$. Znajduje się na nim

75 Por.: Jerzy Rohoziński, Gruzja, Poznań 2016, s. 333.

76 Por.: C. Hourihane, Pontius Pilate, s. 303, il. I48. Kolorową reprodukcję retabulum można obejrzeć na stronie internetowej muzeum: https:/www.monestirs.cat/monst/annex/espa/balear/clarapal.htm, dostęp I3 III 2020. 


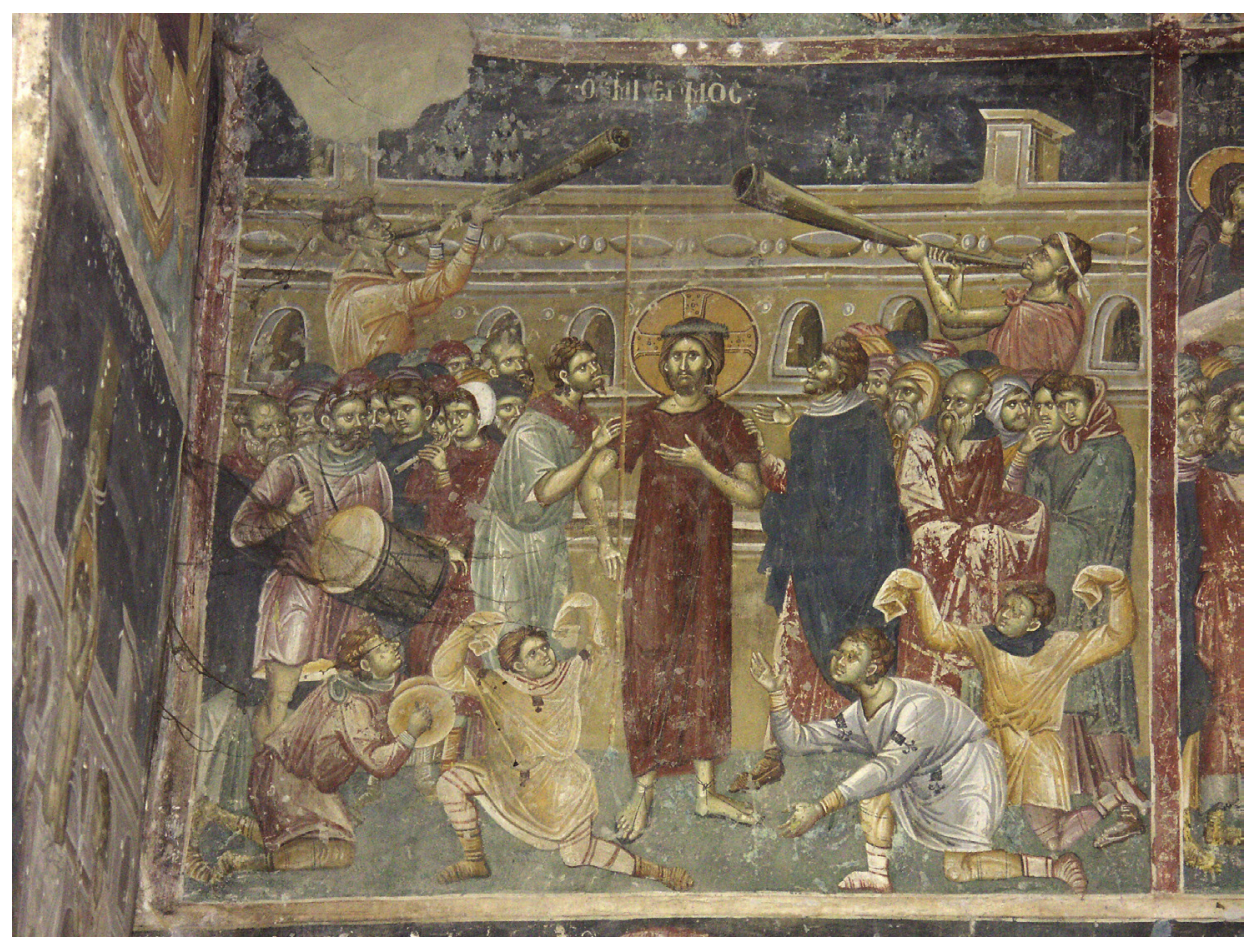

Il. 6. Naigrawanie, malowidło ścienne, ok. I316-I8 r., Michael i Eutychios, kościół św. Jerzego w Staro Nagoričino (Macedonia), Wikimedia CC, Public Domain, https://commons.wikimedia. $\mathrm{org} / \mathrm{w} /$ index.php?curid=19489306, dostęp 30 IV 2020

szereg scen związanych z motywami franciszkańskimi oraz cykl pasyjny, w którym w scenie Naigrawania Chrystusa otacza jedenastoosobowa grupa postaci w długich szatach (nieuzbrojonych) otacza Chrystusa. Wśród nich jest dwóch akrobatów, mężczyzna grający na instrumencie dętym (róg lub szałamaja?) oraz dwaj inni, grający na idiofonach (talerze oraz kwadratowy tamburyn, prawdopodobnie tradycyjny adufe).

Do popularności scen Naigrawania w XIV w. na Bałkanach przyczyniła się po części działalność wędrownych malarzy, m.in. Michaela Astrapasa i Eutychiosa z Tesaloniki, którzy swoje imiona utrwalili na ścianach świątyń w Staro Nagoričino, Banjani-Čučer, w klasztorze Chilandar na Atos i w Tesalonice ${ }^{77}$ (zob. il. 6). W XIV w. podobne malowidła powstały również na terenach ówczesnej Serbii, Grecji, Bułgarii i Wołoszczyzny, w świątyniach fundowanych lub dekorowanych m.in. przez królów i książąt, nierzadko połączonych więzami rodzinnymi z panującą dynastią bizantyńskich Paleologów, bądź spokrewnionych między sobą ${ }^{78}$.

77 Por.: G. Ilnitchi Currie, „The Emergence of a Paradigm”, s. 47-48.

78 Ibid., s. 47-49. 
Polskie malowidła fundowane przez Władysława Jagiełłę mogły być świadomym nawiązaniem do tej tradycji i chęcią podkreślenia prestiżu polskiego władcy.

\section{HIPOTEZY DOTYCZĄCE INTERPRETACJI SCEN NAIGRAWANIA}

\section{Z MOTYWAMI MUZYCZNYMI}

Wciąż nie jest do końca zrozumiałe znaczenie muzycznych motywów w kontekście wyszydzenia Chrystusa. Badacze wysuwali różne hipotezy, ale żadna z nich nie okazała się w pełni przekonująca i wyczerpująca, być może ze względu na nadmierną koncentrację na dosłownej warstwie obrazu i pomijanie szerszego kontekstu, przede wszystkim biblijnego i teologicznego, który w pierwszej kolejności kształtował chrześcijańską ikonografię, ale także kulturowego, historycznego i politycznego. Hipotezy te były zresztą często formułowane tylko jako uwagi na marginesie opracowań dotyczących innych zagadnień. Dopiero w ostatnich latach pojawiły się odrębne prace poświęcone w całości scenom Naigrawania ${ }^{79}$.

Niektórych hipotez przy aktualnym stanie wiedzy nie można już obronić, np. sugestii o istnieniu związku między bizantyńskimi scenami Naigrawania z motywami muzycznymi, a rytualnym hałasem matrymonialnym charivari $^{80}$, komedią dell'arte $^{8 \mathrm{r}}$, czy też późnośredniowiecznymi dramatyzacjami pasyjnymi ${ }^{82}$, choćby z uwagi na dużo wcześniejszą genezę tego motywu w plastyce i jego wyraźne związki z ikonografią cesarską. Mało uzasadniony jest również związek tych scen z fragmentami ksiąg biblijnych opisującymi proroków wyśmiewanych przez dzieci $(2 \mathrm{Krl}, 23 ; 2 \mathrm{Krl} 16,6)$, cierpiącego Sługę Jahwe (Iz 53,7), Hioba (Hi 2I, II-I2), czy z konkretnymi wersetami Psalmów (Ps 68, II-I3) i Lamentacji (Lm 3,4), w których mowa o szyderczych pieśniach ${ }^{83}$. Równie wątpliwy jest wpływ gruzińskiego, czy w ogóle bizantyńskiego teatru religijnego ${ }^{84}$. Nawet gdyby scena taka pojawiła się najpierw na gruncie dramatyzacji, to ustalenie przyczyny wprowadzenia do niej elementów muzycznych wymagałoby odpowiedzi na te same pytania, co w przypadku ikonografii.

79 Zaprezentowane poniżej hipotezy zostały szczegółowo omówione i przeanalizowane w cytowanej już dysertacji doktorskiej autorki niniejszego artykułu.

80 L. Réau, Iconographie de l'Art Chrétien, s. 448; Febo Guizzi, „Corni, strepiti, diavoli e Guidei. Le raffigurazioni del Cristo Deriso e il 'demoniaco' nei rituali della Passione”, w: Charivari. Mascherate di vivi e di morti. Atti del V Convegno Internazionale, Rocca Grimalda, 7-8 ottobre 2000, red. Franco Castelli, Alessandria 2004, s. 217-2I9.

8I F. Guizzi, „Corni, strepiti, diavoli”, s. 2 I2.

82 L. Réau, Iconographie de l'Art Chrétien, s. 448.

83 James H. Marrow, Passion Iconography in Northern European Art of the Late Middle Ages and Early Renaissance, Kortrijk 1979, s. I4I, I45, I49, I54; F. Guizzi, „Corni, strepiti, diavoli”, s. 213-215; K. Keiko, „Notes on the Dancers”, s. I62-I67.

84 E. Privalova, Rospis' Timotesubani, s. 215. 
Trudniejsze do zweryfikowania są sugestie, jakoby sceny te były echem antycznych rytuałów upokarzania jeńców ${ }^{85}$, bądź kronikarskich relacji na temat brutalnego znieważenia bizantyńskich władców i dostojników szyderczymi pieśniami i tańcami $^{86}$. Można tylko założyć, że z czasem ten kontekst stawałby się coraz bardziej odległy, a przez to mniej zrozumiały, zwłaszcza w bardziej oddalonych od Konstantynopola regionach, takich jak chociażby Polska. Tymczasem sceny takie były kopiowane bardzo długo, przez kilka kolejnych stuleci, więc ich przekaz musiał być bardziej uniwersalny.

Niektórzy badacze odczytywali muzykujące i tańczące postaci bardzo dosłownie, jako średniowiecznych wędrownych muzykantów, wesołków, mimów i komediantów, żyjących na bakier z Kościołem i moralnością, a więc reprezentujących w pewnym sensie grzeszników szydzących z Chrystusa ${ }^{87}$. Jednak ta identyfikacja nie wyjaśnia w żaden sposób przyczyny i celu wprowadzenia ich do sceny Naigrawania zamiast lub oprócz żołnierzy, o których mowa w Ewangeliach. W żadnej ze scen biblijnych nie dokonywano tak głębokich zmian bez wyraźnego powodu.

Kluczowym czynnikiem weryfikującym powinien być w tym przypadku fakt, że malowidła te zdobią ściany ortodoksyjnych świątyń, często najważniejszych ze względów religijnych i politycznych, były wykonywane przez pobożnych mnichów i wielokrotnie kopiowane, a więc nie mogły znaleźć się tam bez akceptacji teologów i dostojnych fundatorów. Włączenie do sceny Naigrawania elementów pozaewangelicznych, które miałyby jeszcze bardziej upokorzyć Chrystusa, byłoby wątpliwe moralnie. Scena ta należała do stałego repertuaru, była kopiowana przez długi okres, w wielu odległych od siebie ośrodkach, musiała więc zawierać jakiś istotny, uniwersalny przekaz. Ponaddosłowne znaczenie motywów muzycznych jest tym bardziej prawdopodobne, że wszystkie pozostałe elementy scen Naigrawania, podobnie jak w przypadku pozostałych scen pasyjnych, są zgodne z relacjami Ewangelistów i rzadko zawierają dodatkowe, a zwłaszcza tak zaskakujące elementy.

Choć poszczególne malowidła znacząco różnią się między sobą liczbą postaci, rodzajem ich strojów, instrumentów muzycznych, obecnością lub brakiem żołnierzy, tancerzy, akrobatów, itp., to każde z nich wpisuje się w ogólny model, którego centrum stanowi majestatyczny, pełen godności i spokoju Chrystus w cesarskim płaszczu lub tunice, bez krwawych śladów po biczowaniu. Otaczają go z obu stron postaci w strojach świeckich, a często także uzbrojeni żołnierze. W tłumie pojawia się od dwóch do kilku muzyków grających najczęściej na instrumentach wojskowych, trąbach, rogach, bębnach i talerzach. Rzadko pojawiają się inne instrumenty,

85 S. Radojčić, „Ruganje Hristu na fresci”, s. 15-32; K. Keiko, „Notes on the Dancers”, s. 159.

86 H. Maguire, „Parodies of Imperial Ceremonial”, s. 423-425.

87 S. Radojčić, „Ruganje Hristu na fresci”, s. 15-32; D. Panayotova, Bulgarian Mural Paintings, s. 51; A. Różycka-Bryzek, Freski bizantyńsko-ruskie fundacji Jagietty, s. 86; D. Grabiec, „Musical Motifs in Christ's Passion", s. I84. 
używane w muzykowaniu świeckim, dworskim, a także tancerze i akrobaci, którzy również znajdowali zatrudnienie na europejskich dworach. Wszystkie postaci skoncentrowane są na Chrystusie, kierują się w Jego stronę, niektóre wykonują ceremonialny, głęboki ukłon do ziemi. Nie na wszystkich malowidłach widoczna jest agresja szyderców, wtłaczanie na głowę cierniowego wieńca i uderzanie trzciną. Na wielu, zwłaszcza wczesnych, wielobarwny tłum zachowuje dystans i trudno dostrzec jakieś oznaki przemocy. Tak jest też w przypadku Lublina i Wiślicy. Chociaż niektóre z malowideł zawierają motywy unikatowe, charakterystyczne tylko dla danej kultury lokalnej (jak choćby nietypowy zestaw instrumentów muzycznych w Lublinie), mogące nieść ze sobą jakieś dodatkowe treści, czytelne tylko dla członków danej społeczności ${ }^{88}$, to wydaje się, że wszystkie te sceny należy interpretować według jednego, wspólnego dla nich klucza, nie negując oczywiście możliwości, w niektórych przypadkach, odczytywania dodatkowych znaczeń w kontekście lokalnym. Obecność nowych, nietypowych motywów na późniejszych przykładach (np. tańca z chusteczkami na wielu malowidłach z terenów ówczesnej Mołdawii i Wołoszczyzny ${ }^{89}$ ) mogła być wynikiem stopniowego zacierania się pierwotnego znaczenia scen i powielania wzorca, który wprawdzie utrwalił się w tradycji, ale przestał być do końca zrozumiały ${ }^{90}$.

Kilku badaczy zwróciło uwagę na podobieństwo bizantyńskich scen Naigrawania do ikonografii imperialnej, do ceremonii dworskich, zwłaszcza koronacji i aklamacji ${ }^{91}$, a także do wprowadzonej na początku XII w. w Bizancjum nowej, uroczystej ceremonii z udziałem cesarza, tzw. prokypsis ${ }^{92}$. Uroczystości takie odbywały się przede wszystkim na konstantynopolitańskim Hipodromie, podobnie jak igrzyska, spektakle i egzekucje więźniów, a towarzyszyła im muzyka i tańce ${ }^{93}$. Z traktatów Konstantyna VII Porfirogenety De ceremoniis aulae Byzantinae (X w.) oraz Jerzego Kodinosa De officialibus palatii Constantinopolitani et de officiis magnae ecclesiae liber (XIV w.), opisujących ceremoniał dworski, dowiadujemy się, że

88 Na problem ten zwróciła uwagę Gabriela Ilnitchi w odniesieniu do malowideł z terenu Mołdawii z końca XV i początku XVI w., na których dostrzegła instrumenty wojsk tureckich, które mogły być aluzją do islamskich najeźdźców uciskających kraj i prześladujących wyznawców Chrystusa, por.: G. Ilnitchi, „Ottoman Echoes”, s. 2 IO.

89 Por.: G. Ilnitchi Currie, „Catalogus”, op. cit.

90 O podobnym zjawisku w przypadku malowideł przedstawiających świętych rycerzy pisze Tania Velmans, por.: tejże, „Une image rare de saint cavalier à Chypre et ses origines orientales”, Deltion of the Christian Archaeological Society 30 (2009), s. 233-240.

9I S. Radojčić, „Ruganje Hristu na fresci”, s. I5-32; A. Grabar, L'empereur dans l'art byzantine, s. 66-67, 8I; R. Pejović, Predstave muzickih instrumenata, s. I9; F. Guizzi, „Corni, strepiti, diavoli”, s. 2I2; K. Keiko, „Notes on the Dancers”, s. I59; G. Ilnitchi Currie, „The Emergence of a Paradigm”, s. 47-50, 7I-73. Według A. Gronek postaci akrobatów, mimów, tancerzy i dzieci przypominają uczestników królewskiego orszaku, zob.: A. Gronek, Ikony Męki Pańskiej, s. Ios-Io6.

92 H. Maguire, „Parodies of Imperial Ceremonial”, s. 424.

93 Judith Herrin, Bizancjum. Niezwykte dziedzictwo średniowiecznego imperium, przekł. Norbert Radomski, Poznań 20I4, s. 49-5I, 53, I03, II3, I65, 208, 217. 
uroczystym aklamacjom towarzyszyła cesarska orkiestra złożona przede wszystkim z trąb, rogów, fletów i talerzy94, a właśnie takie instrumenty, z wyjątkiem fletów, pojawiają się najczęściej na bałkańskich malowidłach.

Muzykanci, akrobaci, tancerze, aktorzy przynależeli do społeczności wielu europejskich dworów królewskich i książęcych, ale z uwagi na charakter ich działalności, kojarzonej powszechnie z niemoralnym prowadzeniem się, mieli niską rangę w społeczeństwie ${ }^{95}$. Być może dlatego byli w scenach Naigrawania ukazywani jako łatwo rozpoznawalny element świty królewskiej, ale często w pomniejszonych rozmiarach z uwagi na niski status społeczny. Ich zgromadzenie wokół Chrystusa ubranego w cesarską szatę miało być może zwrócić uwagę nie tyle na szyderstwa, co na królewską godność, bo to ona staje się powodem oskarżenia, a następnie wyszydzenia i skazania.

Chrystus w tym kontekście przypomina więc bardziej prawdziwego władcę otoczonego przez dworzan, muzyków i wojsko, niż wyszydzonego skazańca. Jedynie kontekst pasyjny, trzcina w dłoni, w niektórych przypadkach bose stopy i korona cierniowa wtłaczana na głowę przez żołnierzy oraz ich agresywne gesty przypominają, że chodzi tutaj nie o prawdziwą ceremonię, ale o szyderczą pseudokoronację, czy pseudoaklamację, tak jak ewangeliczne Naigrawanie było parodią hołdu królewskiego urządzoną przez znudzonych żołnierzy ${ }^{96}$. Takie imperialne ujęcie mogło podkreślać duchowy wymiar i symbolikę tego momentu Pasji, kiedy szydercy nieświadomie urągają prawdziwemu Królowi Żydowskiemu, czyli Mesjaszowi, Pomazańcowi ${ }^{97}$.

Nie dysponujemy wieloma przykładami ikonograficznymi, które ukazywałyby w podobny sposób cesarzy otoczonych dworem, orkiestrą i wojskiem, nie wiemy więc, jak dokładnie przebiegały te ceremonie i w jaki sposób, jeśli w ogóle, przedstawiano je w sztuce. Jedyny powszechnie znany wizerunek tego rodzaju to często przywoływany w literaturze obelisk Teodozjusza umieszczony na Hipodromie pod koniec IV wieku. Relief wykuty na podstawie obelisku przedstawia cesarza trzymającego korony przeznaczone dla zwycięzców zawodów, a dookoła niego rzędy dworzan, wojska, a także tancerzy i instrumentalistów (il. 7). Gabriela Ilnitchi Currie przywołuje też miniaturę z madryckiej dwunastowiecznej kopii kroniki Skylitzesa, na której

94 Andrzej Malinowski, „Aklamacje w ceremoniach bizantyńskich”, Musica Antiqua Europae Orientalis, t. 7, Bydgoszcz 1983, s. 323-324.

95 Stana Đjurić-Klajn, A Survey of Serbian Music through the Ages, Belgrade 1972, s. 9-10.

96 Opis Męki Chrystusa w Ewangelii św. Jana jest skonstruowany w taki sposób, że kolejne wydarzenia odpowiadają kolejnym etapom rytuału koronacyjnego królów dawnego Izraela, por.: Ignace de la Potterie, Męka Jezusa Chrystusa wedtug Ewangelii Jana, przekł. Tadeusz Kukułka, Kraków 2006. Na temat przebiegu ceremonii koronacji w starożytnym Izraelu zob.: Roland de Vaux, Instytucje Starego Testamentu, t. I i 2, przekł. Tadeusz Brzegowy, Poznań 2004, s. II4-I2O.

97 Dla Żydów terminy „Król” oraz „Mesjasz”, czyli „Pomazaniec” i „Zbawiciel” były właściwie synonimami, zob.: R. de Vaux, Instytucje Starego Testamentu, s. II8. 


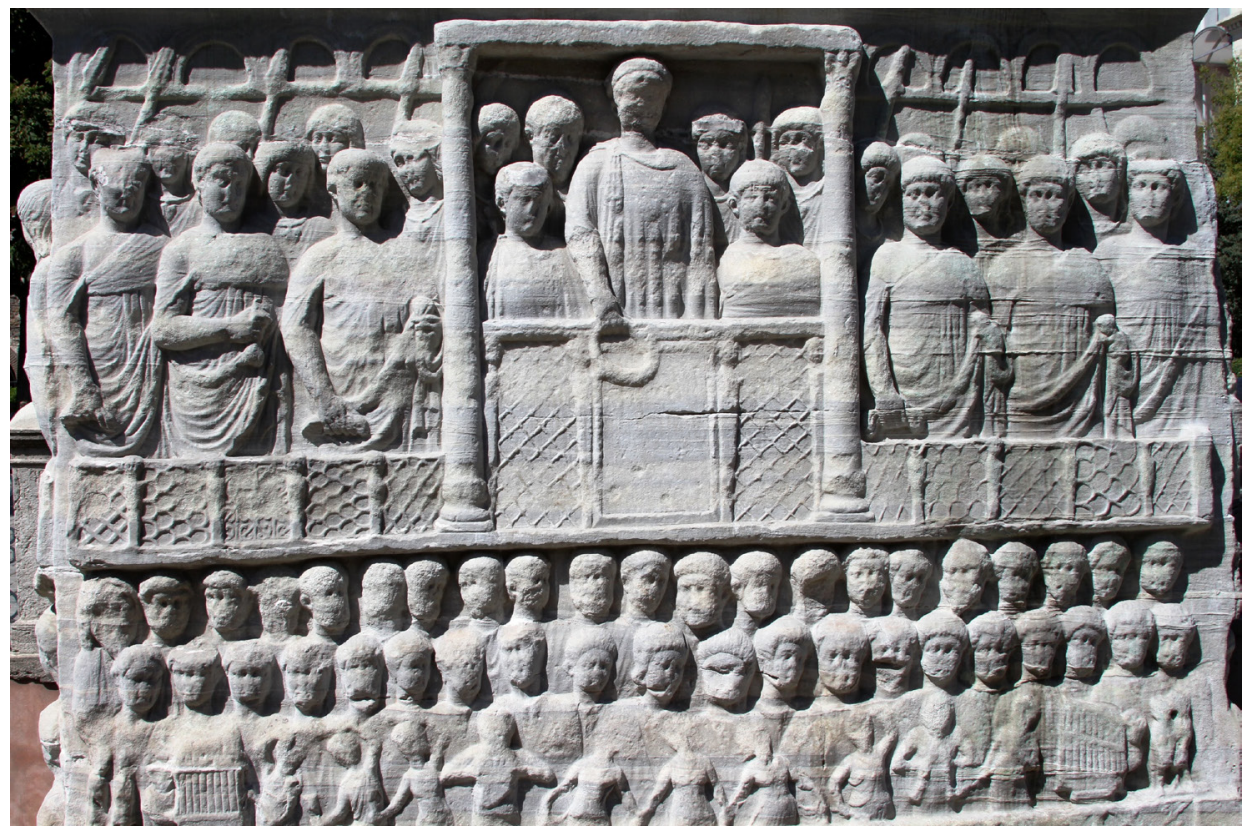

Il. 7. Obelisk Teodozjusza, relief z IV w., anonim, Istambuł, Hipodrom, fot. José Luiz Bernardes Ribeiro, Wikimedia CC BY-SA 3.0, https://commons.wikimedia.org/w/index.php?curid=3026295I, dostęp 22 IV 2020

koronowany cesarz Michał podnoszony jest na specjalnej okrągłej platformie, a po obu jego stronach stoją grupy trębaczy i wiwatującego ludu ${ }^{98}$. Być może tego rodzaju ikonografia stanowiła inspirację dla chrześcijańskich malarzy, którzy nie tyle powtórzyli wiernie jakiś znany świecki model, co zaczerpnęli z niego pewne elementy do sceny Naigrawania, aby przekazać określone treści teologiczne.

Warto bowiem zauważyć podobieństwo bizantyńskich scen Naigrawania, zwłaszcza rozbudowanych scen bałkańskich, do opisu koronacji Joasza w Drugiej Księdze Królewskiej (2Krl II, I2-I4) i Drugiej Księdze Kronik (2Krl 23, I3), gdzie jest mowa o otaczających króla dowódcach i trębaczach oraz o radości ludu, który dmie w trąby, a także o muzykach i śpiewakach wykonujących śpiewy pochwalne. Także sama historia Joasza, podobnie jak Jezus ocalonego jako dziecko z rzezi, która miała unicestwić prawowitych pretendentów do tronu królewskiego, następnie ukrywanego przez lata po to, aby we właściwym momencie otrzymać godność królewską i objąć tron, kładąc kres rządom uzurpatorki Atalii, mogłaby wskazywać na to, że teolodzy widzieli w nim jeden ze starotestamentowych typów Chrystusa, który będzie oczekiwanym Królem, czyli Mesjaszem. Królowi temu towarzyszy ra-

98 G. Ilnitchi Currie, „The Emergence of a Paradigm”, s. 72. 
dość ludu, śpiewy i tańce oraz gra na instrumentach. Podobnie w Psalmach z postacią Króla wiążą się wezwania do radości, tańca, klaskania w dłonie oraz gry na instrumentach, zwłaszcza na trąbach i rogach (Ps 47, 2-3.6-8; Ps 81, 2-4; Ps 95, I-3; Ps 98, 4-6; Ps I49, I-3). Być może więc w scenach Naigrawania te muzyczne motywy miały skierować uwagę widza nie na realne upokorzenie Chrystusa, ale na Jego prawdziwą, królewską tożsamość. Podobnie jak na wczesnośredniowiecznych syro-palestyńskich wizerunkach Ukrzyżowania ukazywano Chrystusa rozpiętego na krzyżu nie nagiego, ale w purpurowym colobium ozdobionym złotymi pasami, nie tylko z szacunku i niechęci do pokazywania nagiego ciała, ale także, aby podkreślić Jego królewską i arcykapłańską godność99, tak w przypadku Naigrawania kompozycja sceny przypominająca koronacje, czy aklamację świeckich władców, miała być może podkreślić to, że wyszydzany i oskarżany o uzurpację Jezus, jest prawdziwym Królem i Mesjaszem.

\section{PODSUMOWANIE}

Bizantyńskie sceny Naigrawania z motywami muzycznymi z Lublina i Wiślicy należą do znacznie starszej niż wcześniej sądzono tradycji ikonograficznej, sięgającej co najmniej początku XII w., i są jej peryferyjnymi, dość późnymi przykładami, zawierającymi nietypowe motywy zaczerpnięte prawdopodobnie z lokalnej kultury, które jednak nie wpływają na zmianę znaczenia samych scen wpisujących się w dojrzały model. Podobnie jak w wielu innych przypadkach, należą do zespołów malowideł ufundowanych przez władców państw w ważnych ośrodkach kultu religijnego. Choć do tej pory były one najczęściej odczytywane w sposób dosłowny, jako wyjątkowo brutalne i upokarzające sceny ogłuszania i ośmieszania poprzez muzykantów, to w świetle nowych hipotez należy brać pod uwagę raczej ich symboliczny, teologiczny wymiar. Kontekst biblijny Naigrawania wskazuje na istotne dla zrozumienia tej sceny znaczenie ceremonii koronacyjnej, która w opisie ewangelicznym ma podwójny wymiar. W sensie dosłownym, zgodnie z relacją literacką, jest ona szyderczą parodią prawdziwego hołdu królewskiego i upokorzeniem ubiczowanego Jezusa, natomiast w znaczeniu symbolicznym jest to moment objawienia się prawdziwej królewskiej godności Chrystusa. Kompozycja z silnymi akcentami imperialnymi i motywami muzycznymi, jakie towarzyszyły dworskim uroczystościom, pozwala dostrzec wyraźną aluzję do koronacji i aklamacji Króla Żydowskiego, Mesjasza, co wprowadza do tej sceny element dwuznaczności, czy raczej dwuwymiarowości.

99 Por. np. sceny Ukrzyżowania na miniaturze z kodeksu Rabuli (ok. 586 r.) z klasztoru św. Jana w Zagba w Mezopotamii (zob.: G. Schiller, Ikonographie der christlichen Kunst, s. IO2), na palestyńskiej kasetce drewnianej z VII lub VIII w. (zob.: ibid., s. IO2-IO4) oraz ikonę Ukrzyżowania z VI w. z klasztoru św. Katarzyny na Synaju (zob.: ibid., il. 330), por. też: Émile Mâle, L'art réligieux du XIIe siècle en France, Paris 1953 , s. 78-82. 


\section{BIBLIOGRAFIA}

Bakalova, Elka. Stenopisite na crkvata pri sielo Berendé. Sofia: Bulgarski Houdozhnik, 1976.

Bałabanov, Kosta. Macedonian Frescoes. Skopje: Detska Radost, I995.

Banach, Jerzy. Tematy muzyczne w plastyce polskiej. Kraków: PWM, I956.

Boeck, Elena. „Simulating the Hippodrome: The Performance of Power in Kiev's St. Sophia”. The Art Bulletin 9I, nr 3 (2009): 283-30I.

Felmy, Karl Christian. Das Buch der Christus - Ikonen. Freiburg: Herder, 2004.

Deluga. Waldemar. „Byzantine Frescoes in Latin Churches of the Jagiellonian Age in Poland and Lithuania: History of the Discover". Arte Christiana Io6, nr 844 (2008): 24-34.

Đjurić-Klajn, Stana. A Survey of Serbian Music through the Ages. Belgrade: Association of Composers of Serbia, 1972.

Floreva, Elena. The Church of the Prophet Eliah in Boboshevo. Sofia: Bulgarski Houdozhnik, I978.

Grabar, André. L'empereur dans l'art byzantin. London: Variorum Reprints, I97I.

Grabiec, Dominika. „Musical Motifs in Christ's Passion: the Mocking of Christ from the Holy Trinity Chapel at Lublin Castle and Miniatures from the Cracovian Dominican meditations (ca. I532)". W: The Musical Heritage of the Jagiellonian Era, red. Pawel Gancarczyk, Agnieszka Leszczyńska, 29-37. Warszawa: Instytut Sztuki PAN, Uniwersytet Warszawski, Biblioteka Narodowa, 20I2.

Grabiec, Dominika. „Przedstawienia Pasji w malarstwie włoskim od XIII do XV w. Próba interpretacji symboliki trąb i rogów”. Dysertacja doktorska, Instytut Sztuki Polskiej Akademii Nauk, 2017.

Gronek, Agnieszka. Ikony Męki Pańskiej. O przemianach w malarstwie cerkiewnym ukraińsko-polskiego pogranicza. Kraków: Collegium Columbinum, 2007.

Gronek, Agnieszka. „O wątku ewangelicznym w bizantyńsko-ruskich malowidłach w wiślickiej kolegiacie”. W: Doctus artifex. Studia ofiarowane profesorowi Jerzemu Gadomskiemu $w$ siedemdziesiąta rocznice urodzin, red. Wojciech Bałus, Wojciech Walanus, Marek Walczak, I79-19I. Kraków: Wydawnictwo Uniwersytetu Jagiellońskiego, PAU, 2007.

Grotowski, Piotr Łukasz. „Dwie nieznane sceny w prezbiterium kolegiaty wiślickiej”. W: Ars graeca. Ars latina. Studia dedykowane Profesor Annie Różyckiej-Bryzek, red. Wojciech Bałus, Waldemar Ceran i in., I45-I54. Kraków: Wydawnictwo Uniwersytetu Jagiellońskiego, 200I.

Grotowski, Piotr Łukasz. „On the Margins of Meaning: Some Remarks on Gesture as Depicted in the Orthodox Frescoes of Roman Catholic Churches in Poland”. Biuletyn Historii Sztuki 70, nr I (2008): I63-I76.

Grzybkowski Andrzej, red., Wiślica: nowe badania i interpretacje. Warszawa: Ośrodek Dokumentacji Zabytków, 1997.

Guizzi, Febo. „Corni, strepiti, diavoli e Guidei. Le raffigurazioni del Cristo Deriso e il 'demoniaco' nei rituali della Passione”. W: Charivari. Mascherate di vivi e di morti. Atti del V Convegno Internazionale, Rocca Grimalda, 7-8 ottobre 2000, red. Franco Castelli, 217-219. Alessandria: Edizioni dell'Orso 2004. 
Herrin, Judith Herrin. Bizancjum. Niezwykte dziedzictwo średniowiecznego imperium. Przekł. Norbert Radomski. Poznań: Rebis, 2014.

Hourihane, Column. Pontius Pilate, Anti-semitism, and the Passion in Medieval Art. Princeton: Princeton University Press, 2009.

Ilnitchi Currie, Gabriela. „Catalogus. A Corpus of Pictorial Representations of Musical Instruments and Dances in the Church Frescoes of Present-day Romania, Wallachia and Moldavia, ca. I350 to ca. I750". Imago Musicae 23 (2006-2010): IOI-I52.

Ilnitchi, Gabriela. „Ottoman Echoes, Byzantine Frescoes, and Musical Instruments in the Balkans". W: Balkan Popular Culture and the Ottoman Ecumene: Music, Image, and Regional Political Discourse, red. Donna A. Buchanan, 194-224. Maryland: The Sacrecrow Press, Lanham, 2007.

Ilnitchi Currie, Gabriela. „The Emergence of a Paradigm: Representations of Musical Instruments in the Palaiologian Depictions of the 'Mocking of Christ'". Imago Musicae 23 (2006-2010): 47-78.

Janocha, Michał. Ukrainskie i biatoruskie ikony świąteczne w dawnej Rzeczpospolitej. Problem kanonu. Warszawa: Neriton, 2002.

Jurkowlaniec, Grażyna. „The Artistic Patronage of Ladislaus Jagiełło. Beyond the Opposition between Byzantium and the Renaissance”. W: Bizancjum a Renesansy. Dialog kultur, dziedzictwo antyku. Tradycja i wspótczesność, red. Michał Janocha i in., 27I-28I. Warszawa: Instytut Badań Interdyscyplinarnych „Artes Liberales” UW, 2012.

Keiko, Kono. „Notes on the Dancers in the Mocking of Christ at Staro Nagoročino”. Deltion of the Christian Archaeological Society 27, nr 4 (2006): I59-I68.

Kozak, Łukasz. „Rota - ośla lira czy psalterium Dawida? Przykład ambiwalencji w średniowiecznej ikonografii muzycznej”. W: Sacrum - obraz i funkcja w spoteczeństwie średniowiecznym, red. Aneta Pieniądz-Skrzypczak, Jerzy Pysiak, II7-I32. Warszawa: Wydawnictwo Uniwersytetu Warszawskiego, 2005.

Kruk, Mirosław P. „Malowidła Graeco opere fundacji Jagiellonów jako postulat unii państwowej i kościelnej oraz jedności Kościoła”. W: Między teologiq a duszpasterstwem powszechnym na ziemiach Korony doby przedtrydenckiej. Dziedzictwo Średniowiecza i wyzwania XV-XVI wieku, red. Wacław Walecki, I45-20I. Warszawa: Wydawnictwo Uniwersytetu Warszawskiego, 2017.

Lidova, Maria. „Creating a Liturgical Space: The Sinai Complex od Icons by Ioannes Tohabi”. W: Vakhtang Beridze Ist International Symposium of Georgian Culture: Georgian Art in the Context of European and Asian Cultures. Proceedings, June 2I-29, 2008 Georgia, red. Peter Skinner, Dimiti Tumanishvili, Anna Shanshiashvili, 226-23I. Tbilisi: Georgian Arts \& Culture Center, 2009.

Lidova, Maria. „The Artist's Signature in Byzantium. Six Icons by Ioannes Tohabi in Sinai Monastery (IIth-I2th Century)". Opera - Nomina - Historiae. Giornale di Cultura Artistica I (2009): 77-98, online http://onh.giornale.sns.it.

Maguire, Henry. „Parodies of Imperial Ceremonial and the Reflections in Byzantine Art”. W: Court Ceremonies and Rituals of Power in Byzantin and the Medieval Mediterranean. Comparative Perspectives, red. Alexander Beihammer, Stavroula Constantinou, Maria Parani, 4I7-43I. Leiden-Boston: Brill, 2013. 
Mâle, Émile. L'art réligieux du XIIe siècle en France. Paris: Librairie Armand Colin, 1953.

Malinowski, Andrzej. „Aklamacje w ceremoniach bizantyńskich”. W: Musica Antiqua Europae Orientalis, 317-337. T. 7. Bydgoszcz: Filharmonia Pomorska, 1983.

Marrow, James. Passion Iconography in Northern European Art of the Late Middle Ages and Early Renaissance. Krotrijk: Van Ghemmert Publishing Company, I979.

Morawska, Katarzyna. Średniowiecze. Część 2: 1320-I500. Warszawa: Sutkowski Edition, 1998 (= Historia Muzyki Polskiej I).

Panayotova, Dora. Bulgarian Mural Paintings of the I4th Century. Sofia: Foreign Languages Press, I966.

Pejović, Roksanda. Predstave muzickih instrumenata u srednjovekovnoj Srbiji. Beograd: Srpska Akademija Nauka i Umetnosti, 1984 .

Perz, Mirosław. „The Sacred and the Profane in Polish Music Sources and Paintings of the Fifteenth Century". W: Ars musica - ars sacra, red. David Hiley, Wolfgang Horn, 4I-56. Tutzing: Hans Schneider, 2007.

Potterie, Ignace de la. Męka Jezusa Chrystusa wedtug Ewangelii Jana. Przekł. Tadeusz Kukułka. Kraków: WAM, 2006.

Privalova, Ekaterina. Rospis' Timotesubani: issledovanie po istorii gruzinskoj srednevekovoj monumental'noj zhivopisi. Tbilisi: Metsniereba, I980.

Radojčić, Svetozar. „Ruganje Hristu na fresci u Starom Nagoričinu”. Narodna Starina 35 (I939): I5-32.

Réau, Louis. Iconographie de l'Art Chrétien. T. II, Iconographie de la Bible. Nouveau Testament. Paris: Presses Universitaires de France, 1957.

Rohoziński, Jerzy. Gruzja. Poznań: Wydawnictwo Poznańskie, 2016.

Różycka-Bryzek, Anna. „Bizantyńsko-ruskie malowidła ścienne w kolegiacie wiślickiej”. Folia Historiae Artium 2 (1965): 47-82.

Różycka-Bryzek, Anna. Bizantyńsko-ruskie malowidta w kaplicy zamku lubelskiego. Warszawa: PWN, I983.

Różycka-Bryzek, Anna. „Bizantyńsko-ruskie malowidła w Polsce wczesnojagiellońskiej: problem przystosowań na gruncie kultury łacińskiej”. W: Polska - Ukraina. Iooo lat sąsiedztwa, red. Stanisław Stępień. T. 2, 307-326. Przemyśl: Południowo-Wschodni Instytut Naukowy w Przemyślu, I994.

Różycka-Bryzek, Anna. „Bizantyńsko-słowiańskie malowidła w gotyckich kościołach Polski pierwszych Jagiellonów”. W: Między Wschodem a Zachodem. Dzieje Lubelszczyzny. T. 6, cz. 2, Kultura artystyczna, red. Tadeusz Chrzanowski, 313-347. Lublin: Lubelskie Towarzystwo Naukowe, 1992.

Różycka-Bryzek, Anna. „Byzantine Frescoes in Medieval Poland”. W: Actes du XXIIème Congrès International d'Histoire de l'art., Budapest, Septembre 1969. T. I, 225-23I. Akadémiai Kiadó, Budapest: 1972.

Różycka-Bryzek, Anna. „Echa tradycji antycznych w bizantyńsko-ruskich malowidłach ściennych Sandomierza i Lublina”. W: Ars auro prior. Studia Joanni Biatostocki sexagenario dictata, red. Julian A. Chrościcki i in., II5-I20. Warszawa: PWN, I98I. 
Różycka-Bryzek, Anna. Freski bizantyńsko-ruskie fundacji Jagietty w kaplicy Zamku Lubelskiego. Lublin: Muzeum Lubelskie, Wydawnictwo UMCS, 2000.

Różycka-Bryzek, Anna. „Ikonografia malowideł ściennych w kaplicy Świętej Trójcy na zamku w Lublinie: wątek starotestamentowy i hagiograficzny”. Zeszyty Naukowe UJ. Prace z Historii Sztuki I2 (1976): 57-IIO.

Różycka-Bryzek, Anna. „Malowidła ścienne bizantyńsko-ruskie”. W: Malarstwo gotyckie $w$ Polsce, red. Adam S. Labuda, Krystyna Secomska. T. I, s. I55-184. Warszawa: Wydawnnictwo DiG, 2004.

Różycka-Bryzek, Anna. „O freskach lubelskich ponownie: uzupełnienia i dopowiedzenia”. W: Kaplica Trójcy Świętej na Zamku Lubelskim. Historia, teologia, sztuka, konserwacja. Materiaty sesji zorganizowanej w Muzeum Lubelskim 24-26 kwietnia 1997, red. Barbara Paprocka, Jan A. Sil, 9I-IO4. Lublin: Muzeum Lubelskie, Polskie Towarzystwo Turystyczno-Krajoznawcze Oddział Miejski w Lublinie, 1999.

Różycka-Bryzek, Anna. „Realia muzyczne w bizantyńsko-ruskich malowidłach w Polsce czasów Jagiełły". W: Empiria w badaniach muzyki, red. Andrzej Rakowski, I82-I85. Warszawa: Akademia Muzyczna im. Fryderyka Chopina, 1986.

Różycka-Bryzek, Anna. „Realizacja bizantyńskiego programu ikonograficznego w polskich kościołach gotyckich na przykładzie malowideł kaplicy lubelskiej I4I8 r.”. W: Sztuka i ideologia XV wieku. Materiaty Sympozjum Komitetu Nauk o Sztuce PAN, red. Piotr Skubiszewski, 403-425. Warszawa: PWN, 1978.

Różycka-Bryzek, Anna. „Tematy maryjne w malowidłach kaplicy Trójcy Świętej zamku lubelskiego: ikonografia i znaczenie, miejsce w programie". W: Ikona liturgiczna. Ewangelizacyjne przestanie ikonografii maryjnej, red. Kazimierz Pek, II5-I48. Warszawa: Wydawnictwo Księży Marianów, I999.

Różycka-Bryzek, Anna. „Uwagi o referacie T.M. Trajdosa pt. Treści ideowe wizerunków Jagiełły w kaplicy Świętej Trójcy na zamku lubelskim”. Biuletyn Historii Sztuki 43 (I98I): 437-443.

Różycka-Bryzek, Anna. „Wyobrażenia aniołów w bizantyńsko-ruskich malowidłach kaplicy Świętej Trójcy w Lublinie I4I8". Folia Historiae Artium I3 (1977): I9-52.

Różycka-Bryzek, Anna. „Zarys historyczny badań nad bizantyńsko-ruskimi malowidłami ściennymi w Polsce”. Biuletyn Historii Sztuki 27 (1965): 175-293.

Rudniewski, Piotr, Mieczysław Samborski. „Problemy związane z pracami konserwatorskimi przy kaplicy Św. Trójcy na zamku w Lublinie”. Ochrona Zabytków 2I, nr 3 (1968): 15-30.

Schiller, Gertrud. Ikonographie der christlichen Kunst. Cz. 2, Die Passion Jesu Christi. Gütersloh: Gütersloher Verlagshaus, 1968.

Semoglou, Athanassios. „Remarques sur certains archaismes iconographiques dans les peintures murals byzantinisantes de la Pologne au XV siècle". Zograf 32 (2008): I5I-I62.

Smorąg-Różycka, Małgorzata. „Bizantyńskie freski w sandomierskiej katedrze: królewski dar na chwałę Bożą czy odblask idei Unii Horodelskiej?”. Zeszyty Naukowe Uniwersytetu Jagiellońskiego. Prace Historyczne I4I, nr 2 (2014): 235-255.

Trajdos, Tadeusz M. „Treści ideowe i kręgi stylistyczne polichromii bizantyńskiej za panowania Władysława II Jagiełły". Zeszyty Naukowe Wydziału Humanistycznego Uniwersytetu Gdańskiego: Slawistyka 3 (1982): 157-I70. 
Trajdos, Tadeusz M. „Treści ideowe wizerunków Jagiełly w kaplicy Św. Trójcy na zamku lubelskim". Biuletyn Historii Sztuki 4I, nr 3 (1979): 316-320.

Vaux, Roland de. Instytucje Starego Testamentu. Przekł. Tadeusz Brzegowy. T. I-2. Poznań: Pallottinum, 2004.

Velmans, Tania. La Tétraévangile de la Laurentienne, Florence, Laur.VI23. Paris: Éditions Klincksieck, I97I.

Velmans, Tania. „Une image rare de saint cavalier à Chypre et ses origines orientales”. Deltion of the Christian Archaeological Society 30 (2009): 233-240.

Walkowiak, Marcin. „Graeco opere in Władysław Jagiełło’s Royal Power Theatre. Introduction to the Study". Res Historica 48 (2019): 77-IOI.

Weyl Carr, Annemarie. „Icons and the Object of Pilgrimage in Middle Byzantine Constantinople”. Dumbarton Oaks Papers 56 (2002): 75-92.

Żuk-Orysiak, Jolanta. „Historia konserwacji malowideł bizantyńsko-ruskich z kaplicy Trójcy Świętej w Lublinie”. Roczniki Humanistyczne 62, nr 7 (20I4): 53-75.

THE RUTHENIAN-BYZANTINE SCENES OF THE MOCKING OF JESUS AT THE WIŚLICA COLLEGIATE CHURCH AND THE HOLY TRINITY CHAPEL AT LUBLIN'S ROYAL CASTLE, IN THE LIGHT OF RESEARCH AND INTERPRETATIONS TO DATE

The Ruthenian-Byzantine frescos found in the Holy Trinity Chapel at Lublin's Royal Castle and the Collegiate Church of the Nativity of the Blessed Virgin Mary in Wiślica have already been the subject of numerous studies. Funded by Polish king Władysław II Jagiełło late in the I4th c. (Wiślica) and in the early I5th c. (Lublin, I4I8), they are one of several sets of Eastern-style paintings in Poland's major churches. Even though the original composition of the scenes of the Mocking of Jesus in Wiślica and Lublin, with their musical motifs, has long attracted the interest of art historians and musicologists, those motifs have not been studied in detail so far. Scholars have usually limited themselves to a literal interpretation of the role of musicians as jeerers whose task is to deafen and deride Jesus with the cacophony of their music. However, the latest research into the Byzantine scenes of the Mocking of Jesus comprising musical motifs points to completely different directions of interpretation.

The earliest such scenes, with depictions of music instruments and dance, dated to the turn of the IIth and I2th centuries, are found in the form of miniatures in Byzantine Books of the Gospels, and in icons by a Georgian monk preserved in St Catherine's Monastery on Mount Sinai. The very idea of incorporating musical motifs into the Passion narrative had most likely appeared somewhat earlier among artists from Constantinople. Early in the 13 th century such scenes were already known in Georgia (the monasteries in Timotesubani and Ozaani), while toward the end of the same century they can be found in the Balkans, where they attained their most developed, mature form, as well as in the Franciscan retabulum from Majorca. In the I4th and I5th centuries they were particularly popular in today's Serbia, Macedonia, Kosovo, Greece, and Bulgaria. From the I6th century, numerous copies are found in Romania and Wallachia. The most recent such paintings are dated to the 18 th century. The Polish works were inspired by those from the Balkans. However, detailed analysis reveals 
unique and original solutions, as well as an untypical choice of music instruments, which may reflect our local musical culture, or represent the musicians then active at King Jagiełło's court.

Literature of the subject offers many very different interpretations of the Balkan scenes of the Mocking of Jesus, among others, in the context of the charivari, commedia dell'arte, or Passion plays. Some scholars have suggested links to the ancient rituals of humiliating prisoners-of-war, or to historical instances of insulting Byzantine emperors and dignitaries with bantering dances and songs. The paintings have also been interpreted in Biblical contexts, namely, those that refer to the suffering of the just. Most convincing, however, are the elements of ancient imperial iconography and the indebtedness of the overall composition to scenes of emperors' coronations. Through such references, painters and theologians seem to have aimed to emphasise the mocked Christ's royal dignity as the true King of the Jews and Messiah. Musical elements were to bring to mind courtly ceremonies as well as the Psalms that invite the listeners to play, sing and dance in honour of the Lord and King.

The Polish paintings from Wiślica and Lublin draw on the Balkan tradition and are an interesting example of influences from geographically remote areas as well as transformations taking place in the peripheral regions.

Translated by Tomasz Zymer

Słowa kluczowe / keywords: sceny Naigrawania / Mocking scenes, freski bizantyńsko-ruskie / RuthenianByzantine frescoes, Kaplica Świętej Trójcy w Lublinie / Holy Trinity Chapel in Lublin, Zamek Królewski w Lublinie / Royal Castle in Lublin, kolegiata w Wiślicy / Collegiate in Wiślica, średniowieczne instrumenty muzyczne / medieval musical instruments, ikonografia muzyczna / musical iconography

Dr Dominika Grabiec, muzykolog i italianistka, od 2008 r. pracuje w Instytucie Sztuki PAN, gdzie w ramach prac Katalogu Źródeł Muzycznych przygotowuje m.in. bibliografię ikonografii muzycznej w Polsce oraz bazę danych polskich potrydenckich rękopisów chorałowych. W $2017 \mathrm{r}$. uzyskała stopień doktora w zakresie nauk o sztuce na podstawie dysertacji pt. Przedstawienia Pasji $w$ malarstwie wtoskim od XIII do XV w. Próba interpretacji symboliki trąb i rogów. Od 2017 r. współpracuje z Instytutem Historii Nauki PAN w ramach projektu Manuscripta.pl. Jej główne dziedziny badań to ikonografia muzyczna, średniowieczna kultura muzyczna oraz rękopisy liturgiczno-muzyczne. Jest autorką kilkunastu artykułów naukowych na temat ikonografii muzycznej, rękopisów chorałowych oraz osiemnastowiecznych muzykaliów m.in. Szymona Ferdynanda Lechleitnera.

dominika.grabiec@ispan.pl 


\section{JÓZEF ELSNER}

UTWORY FORTEPIANOWE PIANO WORKS

○

PIEŚNI

SONGS
MSZE OP. 26, 35, 42, 62, 75 MASSES OPP. 26, 35, 42, 62, 75

OPERA KRÓL $E O K I E T E K$ CZYLI WIŚLICZANKI

\section{Monumenta Musicae in Polonia}

REDAKTOR • EDITOR

Barbara Przybyszewska-Jarmińska
Seria - Series E

Opera Selecta 